\title{
EL CASTIGO DE LA DISIDENCIA EN LAS INVENCIONES PLÚMBEAS DE GRANADA. SACROMONTE VERSUS IGNACIO DE LAS CASAS
}

\author{
MANUEl BARRios Aguilera \\ Universidad de Granada
}

\section{Unas consideraciones previas}

La sucesión de hallazgos fraudulentos y acontecimientos derivados que comenzó con el exploratorio de Torre Turpiana, el 18 de marzo de 1588 , y terminó con la sentencia condenatoria de las falsificaciones arqueológicas de la Alcazaba en 1777, constituye una sola historia, sobre cuya realidad unitaria no debe engañar su desmedida duración ${ }^{1}$. Ésta es conclusión lógica de un análisis de cierta extensión sobre los defensorios ${ }^{2}$ del siglo XVIII, que enlazan con toda la literatura laminaria ${ }^{3}$ del siglo XVII - diversa de forma y alcance; también, de origen - que antecedió a la condena romana de los libros plúmbeos en 1682. Empero, es necesario profundizar esta idea, que acaso pueda parecer obvia, pero que no ha sido expuesta de forma circunstanciada, pues los que han estudiado monográficamente los fraudes de Juan de Flores, de 1754 a 1763, han prescindido del significado de los defensorios setecentistas, que arrancan con las Vindicias catholicas granatenses, de Diego de la Serna Cantoral, publicadas en Lyon en 1706, y, en su expresión mayor ${ }^{4}$, terminan con la redacción de la

1 Vid. mi artículo «Granada en escorzo. Luis Francisco de Viana y la historiografía del Sacromonte», Demófilo, 35 (2000), 45-80.

${ }^{2} \mathrm{Me}$ atengo a la definición que hace el $D R A E$ del término defensorio: «Manifiesto, escrito apologético en defensa o satisfacción de una persona o cosa». El término es usado por los propios autores de los escritos; la licencia por mi parte es la aplicación generalizada al total de los mismos, dado que la forma y estructura de los contemplados es muy diversa: el núcleo del Místico ramillete, la segunda flor, de Heredia Barnuevo, es una biografia del arzobispo Pedro de Castro en forma de anales... Vid. lo que decimos en el apartado III, infra.

${ }^{3}$ Utilizaré los términos laminario y antilaminario haciendo mía la explicación que ofrece el profesor G. Morocho en el trabajo que se cita abajo. En todo caso, es una opción clara y cómoda.

${ }_{4}$ Tiene su interés, aunque como obra menor, el Ynventario de todos los documentos

Al-Qantara XXIV, 2 (2003) 477-532 
Historia authéntica del hecho de los dos descubrimientos de Torre Turpiana y Monte Santo de Granada, por los canónigos sacromontanos Luis Francisco de Viana y Bustos y Joseph Juan de Laboraría, respondiendo al encargo de Fernando VI en 1756.

Sólo a partir de la aceptación como premisa de ese largo continuum histórico es comprensible el hecho de que el conocido episodio del enfrentamiento Castro-Las Casas se considere desde una fuente tan tardía como 1756. Es imprescindible asumir, asimismo, que los defensorios del XVIII fueron pieza clave en la cristalización del llamado espiritu sacromontano que empezó a gestarse en vida del fundador, y que, con formas degradadas, ha permanecido hasta nuestros días 5: consistía en la defensa y vindicación de las invenciones plúmbeas contra cualquier intento de negación, viniera de donde viniera, fuera cual fuera su naturaleza, como razón de ser de las fundaciones de don Pedro de Castro y Quiñones, las abaciales del Sacromonte, y, en definitiva, de la obra toda del décimo arzobispo de Granada, incluido el Concepcionismo, el corolario más duradero, más trascendente por su universalidad, del que fue campeón victorioso en su pontificado sevillano (1610-1623).

Ciertamente los defensorios setecentistas fijan y afirman las pautas de conducta de la institución y de su ámbito de influencia para el futuro, pero también contribuyen de manera decisiva a la reelaboración global de la historia de Granada, la capital y su reino, reforzando la imagen monolítica y exclusiva del pasado de naturaleza cerradamente contrarreformista - y negadora de la Granada islámica que la precedió - que habían creado las historias eclesiásticas seiscentistas (de Antolínez de Burgos, Bermúdez de Pedraza, Pedro Suárez, Pascual y Orbaneja, Roa...) y asimiladas, principal vehículo divulgador de las invenciones sacromontanas y de sus enseñanzas y aplicación doctrinal y devocional ${ }^{6}$.

pertenecientes a los descubrimientos..., del canónigo sacromontano Joseph Miguel Moreno, partes primera y segunda, manuscritos C.26 y C.27 (en la catalogación de M. J. Hagerty, vid. infra), del que hago uso en "Granada en Escorzo» (vid.). Moreno es un epígono, activo y combativo, de Viana, de cuya dinámica vindicativa estaba imbuido.

5 Vid. mis artículos: «El bucle metahistórico. Los libros plúmbeos de Granada, realidad histórica y mito», Fundamentos de Antropología, 10-11 (2001), 321-333, y «El Sacromonte de Granada o el mito incesante», El Fingidor, 13-14 (julio-dic., 2001), 11-14.

${ }^{6}$ Vid. mi libro reciente Granada morisca, la convivencia negada. Historia y textos, Granada, Comares, 2002, 482-490. 
El notable itinerario biográfico de Ignacio de las Casas - vid. infra-, la significación social y el empeño en la «línea de evangelización pacífica» ${ }^{7}$ de los de su nación, queda minimizado ante el suceso de los libros plúmbeos, cuya recusación radical fue razón de ser de su vida, en la que gastó preciosas energías, implicando las influencias y el prestigio que ganara en las otras actuaciones. Ésta, rayana en la obsesión, le acarreó un sinfín de trabajos, a lo largo de una decena de años, pero sobre todo de preocupaciones y contrariedades que debieron contribuir a acelerar su muerte, no siendo de salud robusta, justamente cuando la autoridad moral por su labor misional, tan fatigosamente ganada, habría podido ser de alguna utilidad a los suyos ante la inminente erradicación de los reinos hispanos. La alargada sombra del arzobispo Castro persiguió su descrédito en vida, ante la impotencia de reducirlo; pero no lo amilanó, por contra, le hizo crecerse, y, hasta poco antes de la muerte, el jesuita morisco siguió rebatiendo los fraudes plúmbeos, incluyendo las reliquias, que consideraba de idéntica naturaleza falsaria, mediante el envío de alegatos a las cortes de Madrid y Roma.

El gran enemigo le sobrevivió por tres lustros. El nombre de Las Casas se convirtió, a contrario, en argumento fundamental para anudar el «espíritu sacromontano», que conllevaba la persecución de la memoria del disidente, su demonización. Y es que la actuación de los antilaminarios armó de razón la fanática determinación de Castro; y de entre todas, la de Las Casas, ciertamente la más pugnaz, pero también la más flagrante en la opinión del arzobispo, pues aparte de pertenecer a una orden, la Compañía de Jesús, generalmente afecta al hecho sacromontano y a la persona de su fundador, había traicionado la confianza que en principio le otorgara en buena medida merced al aval de la orden...

La abundancia y dispersión de los trabajos sobre estas materias obliga a hacer aquí, al comienzo mismo de esta aportación, una mínima reflexión biblio-historiográfica. El fondo doctrinal de la controversia lo acaba de estudiar monográficamente Rafael Benítez Sánchez-Blanco con precisión y cuidado ${ }^{8}$, sumando sus trabajos a las

\footnotetext{
7 Por utilizar la expresión de Melquíades Álvarez Andrés, La Teología española en el siglo XVI, Madrid, BAC, 1976, I, 345, que recrea su sentido meyorativo, frente a la más habitual, la evangelización compulsiva.

8 «De Pablo a Saulo: traducción, crítica y denuncia de los libros plúmbeos por el $\mathrm{P}$. Ignacio de las Casas, S. J.», Al-Qantara, XXIII, fasc. 2 (2002), 33-66; también, «Mesia-
} 
sólidas - tan sólidas como críticas - aportaciones de Gaspar Morocho Gayo, hechas al hilo de la cuantiosa introducción al Discurso sobre el pergamino y las láminas de Granada, de Pedro de Valencia 9. Quedo, pues, liberado de entrar en ello; pero es de prevenir la necesidad de tener esas cuestiones doctrinales como referencia, tanto como el detalle de la vida, la obra misional y la acción social de Las Casas, competentemente explayadas - y muy bien incardinadas en la labor de la orden jesuítica - por Francisco de Borja de Medina hace unos años ${ }^{10}, \mathrm{y}$, recientemente, completadas por Youssef El Alaoui, al analizar en concreto sus propuestas escritas de evangelización y asimilación de los moriscos ${ }^{11}$. Es igualmente necesario tener cuenta del largo proceso de los hallazgos de la Torre Turpiana y de Valparaíso, el gran tesoro de Castro, que por fortuna goza de una bibliografía moderna de cuatro décadas ${ }^{12}$, en general competente: parte de ella, con merecida vitola de clásica ${ }^{13}$; otra, muy reciente, bien documentada y

nismo y milenarismo morisco: los plomos del Sacromonte en la interpretación del jesuita Ignacio de las Casas», en Actas de la VI Reunión de la Fundación de Historia Moderna, [Alcalá de Henares], en prensa (agradezco al autor que me haya proporcionado el original de este trabajo).

${ }_{9}$ «Estudio introductorio del Discurso de Pedro de Valencia sobre el pergamino y láminas de Granada", en Pedro de Valencia, Obras completas. Volumen IV. Escritos sociales. 2. Escritos políticos, León, Universidad, 1999, 143-357.

10 «La Compañía de Jesús y la minoría morisca», Archivum Historicum Societatis Iesu, 57 (1988), 3-134.

11 «Ignacio de las Casas, jesuita y morisco», Sharq al-Andalus, 14-15 (1997-1998), 317-339.

${ }_{12}$ Con el brillante antecedente, por muchos conceptos excepcional, de la Historia crítica de los falsos cronicones, de José Godoy Alcántara, Madrid, Real Academia de la Historia, 1868 (reeditada en facsímil, Granada, Universidad, 1999, con estudio preliminar, muy valioso, de O. Rey Castelao)

${ }_{13}$ Por orden alfabético: La Abadia del Sacromonte, Granada, Universidad, 1974; Alonso, C., O. S. A., Los apócrifos del Sacromonte (Granada). Estudio histórico, Valladolid, Ed. Estudio Agustiniano, 1979; Bonet Correa, A., «Entre la superchería y la fe: el Sacromonte de Granada", en Andalucia monumental. Arquitectura y ciudad del Renacimiento y el Barroco, Sevilla, Biblioteca de Cultura Andaluza, 1986, 31-52; Cabanelas Rodríguez, D., O.F.M., El morisco granadino Alonso del Castillo. Estudio preliminar de J. Martínez Ruiz, Granada, Patronato de la Alhambra y Generalife, ${ }^{2} 1991$ ( $\left.{ }^{1} 1965\right)$; «El Sacromonte, punto de confluencia doctrinal entre el Islam y la Cristiandad», en La Abadia del Sacromonte, 30-40; «Un intento de sincretismo islamo-cristiano: los Libros plúmbeos de Granada», en Actas del II Congreso Internacional sobre las Culturas del Mediterráneo Occidental, Barcelona, 1978, 131-142; «Intento de supervivencia en el ocaso de una cultura: los libros plúmbeos de Granada», Nueva Revista de Filología Hispánica, XXX-2 (1981), 334-358, y otras pequeñas monografias sobre Arias Montano, Miguel de Luna...; Caro Baroja, J., Las falsificaciones de la Historia (en relación con la de España), Barcelona, Seix Barral, 1992; Gómez de Liaño, I., Los juegos del Sacromonte, Ma- 
con fuerte carga renovadora ${ }^{14}$. Vale, en fin, la constatación de que en los últimos tiempos se ha afrontado, cada vez como mejor fundamen-

drid, Editora Nacional, 1975; Hagerty, M. J., Los Libros plúmbeos del Sacromonte, Madrid, Editora Nacional, 1980. (Estudio y edición de la versión del marqués de Estepa); «La traducción interesada: el caso del marqués de Estepa y los libros plúmbeos», en $\mathrm{Ho}$ menaje al prof. Jacinto Bosch Vila, Granada, Universidad, 1991, II, 1179-1186; Kendrick, T. D., Saint James in Spain, London, Methuen, 1960; Martín Palma, J., «Realidad del mito sacromontano», en La Abadía del Sacromonte, 11-17; Martínez Ruiz, J., «Cartas de Thomas van Erpen (Thomas Erpenius) en un archivo de Granada», Boletín de la Real Academia Española, LV (1975), 265-306... La obra del abad Zótico Royo Campos, en su conjunto y, concretamente, el libro más legible, Reliquias martiriales y Escudo del Sacro Monte, Granada, Universidad (Col. Archivum), 1995 (es edición fasímil de la de 1960, estudio preliminar de M. L. López Muñoz), es la de un anacrónico apologista; la forma en que maneja los datos, aun partiendo del archivo sacromontano, es de una tendenciosidad inadmisible en el tiempo en que se redactó y publicó.

14 Bernabé Pons, L. F., «Los mecanismos de una resistencia: los libros plúmbeos del Sacromonte y el Evangelio de San Bernabé», Al-Qanțara, XXIII, fasc. 2 (2002), 477-498; Calatrava, J., "Encomium urbis: la Antigüedad y excelencias de Granada (1608) de Francisco Bermúdez de Pedraza», en Actas del II Coloquio Iglesia, sociedad y cultura en el Reino de Granada (Guadix, 2001), en prensa, y «Granada en la historiografia religiosa seicentista: la Historia eclesiástica de Bermúdez de Pedraza (1639)», en La Historia del Reino de Granada a debate. Viejos y nuevos temas. Perspectivas de estudio, en prensa (agradezo al autor me haya proporcionado los originales de estas dos colaboraciones antes de su publicación); Cuende Plaza, M. ${ }^{\mathrm{a}}$, «Santiago entre los moriscos (I y II). Los libros plúmbeos del Sacromonte», Boletín de la Asociación Española de Orientalistas, XXXIII (1997), 131-153, y XXXIV (1998), 89-112; Harris, A. K., «Forging History: the Plomos of Granada in Francisco Bermúdez de Pedraza's Historia eclesiástica», Sixteenth Century Journal, XXX, 4 (1999), 945-966; Harvey, L. P. y Wiegers, G., "The Translation from Arabic of the Sacromonte Tablets y and the Archbishop of Granada: an illuminating correspondence», Qurțba, 1 (1996), 59-78; Magnier, G., «The dating of Pedro de Valencia's Sobre el pergamino y láminas de Granada», Sharq al-Andalus, 14-15 (1997-1998), 353-373; Martín Palma, J., La última crisis de la Abadia del Sacromonte. Veinticinco años de historia (1950-1975), Granada, Arzobispado, 1995; Martínez Medina, F. J., «El Sacromonte de Granada y los discursos inmaculistas postridentinos», Archivo Teológico Granadino, 59 (1996), 5-57; «El Sacromonte y los sacromontes: mito y realidad», Proyección, 44 (1997), 3-22; «El Sacromonte de Granada, un intento de reinculturación entre la guerra de los moriscos y su definitiva expulsión», Chronica Nova, 25 (1998), 349-379; Mondéjar, J., «Estudio preliminar» a Luis de la Cueva, Diálogos de las cosas notables de Granada y lengua española y algunas cosas curiosas, Granada, Universidad, 1993, VII-L; Ollero Pina, J. A., «La carrera, los libros y la obsesión del arzobispo D. Pedro de Castro y Quiñones (1534-1623)», en De libros y bibliotecas (Homenaje a Rocio Caracuel), Sevilla, 1994; Rubiera Mata, M. ${ }^{a}$ J., «La familia morisca de los Muley-Fez, príncipes meriníes e infantes de Granada», Sharq al-Andalus, 13 (1996), 159-167; Sotomayor, M., S. J., «Introducción» a Justino Antolínez de Burgos, Historia eclesiástica de Granada, Granada, Universidad, 1996, IX-LXII; Vincent, B., «Et quelques voix de plus: de Francisco Núñez Muley à Fátima Ratal», Sharq al-Andalus, 12 (1995), 131-145; Wiegers, G. A., «The Old or Turpiana Tower in Granada and its Relics according to Ahmad b. Qâsim al-Hajarî̀, en Sites et monuments disparus d'après les témoignages de voyayeurs, Lovaina, 1996, 191-205... 
to documental y más adecuado utillaje metodológico, buen número de cuestiones adyacentes, algunas de especial importancia por su estrecha imbricación, para aprehender la temática central de forma fina y matizada ${ }^{15}$, tal como se acredita en varios trabajos de la primera en-

15 Álvarez Barrientos, J., «Historia y religiosidad popular en las falsificaciones granadinas del siglo XVIII», en L. C. Álvarez Santaló y otros, La religiosidad popular. 1. Antropología e historia, Barcelona, Anthropos y Fundación Machado, 1989, 348-356; Álvarez Barrientos, J. y Mora Rodríguez, G., «El final de una tradición. Las falsificaciones granadinas del siglo XVIII», Revista de Dialectología y Tradiciones Populares, XL (1985), 163-189; Barrios Aguilera, M., «Un ensayo de revisión historiográfica de los martirios de las Alpujarras de 1568», ensayo introductorio a F. A. Hitos, Los mártires de la Alpujarra en la rebelión de los moriscos (1568), Granada, Universidad, 1993, VII-LXVI; «El Reino de Granada en la época de Felipe II a una nueva luz. De la cuestión morisca al paradigma contrarreformista», en J. Martínez Millán, dir., Felipe II (1527-1598). Europa y la Monarquía católica, Madrid, Parteluz, 1998, III, 63-88; «Granada en escorzo»; «El bucle metahistórico»; «El Sacromonte de Granada o el mito incesante»; Granada morisca, la convivencia negada, particularmente, 482 ss.; «Las misiones en la sociedad posrepobladora: las del Sacromonte», en La Historia del Reino de Granada a debate, en prensa; Barrios Aguilera, M. y Sánchez Ramos, V., Martirios y mentalidad martirial en las Alpujarras. De la rebelión morisca a las Actas de Ugíjar, Granada, Universidad, 2001; Bernabé Pons, L. F., El Evangelio de San Bernabé. Un evangelio islámico español, Alicante, Universidad, 1995; El texto morisco del Evangelio de San Bernabé, Granada, Universidad e Instituto Juan Gil Albert, 1997; «Estudio preliminar» a Miguel de Luna, Historia verdadera del rey don Rodrigo, Granada, Universidad, 2001, VII-LXX; «La nostalgia granadina de los moriscos», en J. A. González Alcantud y A. Malpica Cuello, eds., Pensar la Alhambra, Anthropos y Diputación de Granada, 2001, 165-181; «Una nota sobre Ahmad ibn Qāsim al-Haŷarī Bejarano», Sharq al-Andalus, 13 (1996), 123-128; «La asimilación cultural de los musulmanes de España: lengua y literatura de mudéjares y moriscos», en B. Bennassar y R. Sauzet, eds., Chrétiens et musulmans à la Renaissance. Actes du 37 Colloque International du CESR (1994), Paris, Honoré Champion Éditeur, 1998, 317-335; «Una visión propicia del mundo: España y los moriscos de Granada», en A. Stoll, ed., Averroes Dialogado y otros momentos literarios y sociales de la interacción cristiano-musulmana en España e Italia. Un seminario interdisciplinar, Kassel, Edition Reichenberger, 1998, 89-137; Córdoba, P., «Las leyendas en la historiografia del Siglo de Oro: el caso de los falsos cronicones», Criticón, 30 (1985), 235-353; Labarta, A., «Notas sobre algunos traductores de árabe en la Inquisición valenciana», Revista del Instituto Egipcio de Estudios Islámicos en Madrid, 21 (1981-1982), 103-112; Márquez Villanueva, F., «La voluntad de leyenda de Miguel de Luna», en El problema morisco (desde otras laderas), Madrid, Ed. Libertarias, 1991, 4597; Orozco Pardo, J. L., Christianópolis: urbanismo y contrarreforma en la Granada del seiscientos, Granada, Diputación, 1985; Rey Castelao, O., La Historiografía del Voto de Santiago. Recopilación critica de una polémica histórica, Santiago de Compostela, Universidad, 1985; «Estudio preliminar» a J. Godoy Alcántara, Historia crítica, VII-XCVII; Rodríguez Ruiz, D., La memoria frágil. José de Hermosilla y las antigüedades árabes de España, Madrid, Fundación Cultural COAM, 1992 (en especial, cap. 3); Roldán Hervás, J. M., Juan de Flores y las excavaciones del Albayzin. Arqueología y fraude en la Granada del siglo XVIII, Granada, Azur, 1983; Sotomayor, M., S. I., Cultura y picaresca en la Granada de la Ilustración. D. Juan de Flores y Oddouz, Granada, Universidad, 1988... 
trega del reciente dossier de esta misma revista en torno a los plomos ${ }^{16}$. Éstas son las bases bibliográficas de partida - necesariamente selectivas, pero actualizadas - inexcusables para una adecuada comprensión de nuestra aportación.

He dejado escrito en otros lugares, aun con reiteración ${ }^{17}$, mi convencimiento de que los defensorios setecentistas forman parte de un programa vindicativo del que la Historia authéntica, de Viana-Laboraría, constituyen el cuarto gran acto - los otros son las Vindicias de La Serna, el Mistico ramillete de Heredia Barnuevo y las Guerras cathólicas granatenses de Pastor de los Cobos, de las que más abajo me ocuparé-. Quedaría un nuevo acto (una especie de sonoro estrambote), pues así lo entiendo - antes de entrar en el siglo XIX, de distinta actitud ante estos hechos- el fraude de la Alcazaba de 1754-1763, pese a que se presente bajo especie arqueológica (a diferencia de los cuatro anteriores que tienen el más convencional soporte histórico-literario); por algo el fautor intelectual de este fraude llamativo es el canónigo Viana, como se demostró en su tiempo ${ }^{18}$. De otra parte, no es aventurado imputarle la autoría mayor de la Historia authéntica. De los muchos seguidores espirituales de Castro, el más entusiasta, activo, capacitado y eficaz fue Viana. Da fe de ello esta historia, a poco que se la sepa leer, $y$, de forma eminente, el tratamiento del suceso de Las Casas.

Así, antes de pasar a su glosa, creo obligado debelar la inadvertencia metodológica que supone haber explayado el fraude de la Alcazaba, dejándose arrastrar por la sugestión novelesca - e induciendo al lector hacia la vertiente fabulosa-, sin enlazarlo circunstanciadamente con el programa vindicativo inmediato anterior, es decir, con los defensorios aludidos, que componen con él un todo indisoluble, hasta el punto de explicarlo en gran medida. No basta aceptar la conexión ideológica de los fraudes alcazabinos con las invenciones de fi-

${ }^{16}$ Al-Qanțara, XXIII, fasc. 2 (2002): Ecker, H. L. «“Arab Stones”. Rodrigo Caro's traslations of Arabic inscriptions in Seville (1634), revisited», 347-402; Rodríguez Mediano, F. y García-Arenal, M., «Diego de Urrea y algún traductor más: en torno a las versiones de los "plomos"», 499-516; Harris, K. H., «The Sacromonte and the Geography of the Sacred in Early Modern Granada», 517-543.

17 En los trabajos citados: «Granada en escorzo»; «El bucle metahistórico»; «El mito incesante»; Granada morisca, la convivencia negada.

18 Vid. Razón del juicio seguido en la ciudad de Granada... contra varios falsarios de escrituras públicas, monumentos sagrados y profanos, tradiciones, reliquias y libros de supuesta antigüedad. Madrid, Ibarra, 1781, passim. 
nes del XVI, por otra parte demasiado obvia: es necesario reconstruir en todas sus dimensiones, en todos sus matices, el puente que une la condena romana de 1682 con las supercherías arqueológicas de Juan de Flores y Oddouz y de sus socios y ayudadores. La atención interesada que estos sucesos siguen despertando en los medios eclesiales ${ }^{19}$ podría hacer pensar que este tipo de tratamientos selectivos - acaso, tácticamente reduccionistas - es una incitación subliminar a atenuar la responsabilidad institucional de la Abadía del Sacromonte - $-\mathrm{y}$, como poco, de la connivente Iglesia granadina - trivializando unos hechos cuyo cabal conocimiento cuestiona, si no invalida, la legitimidad de su mensaje y afloja el valor de su legado.

Nada tiene de extraño que la mitología basada en la Ilíberis alcazabeña - los Gómez-Moreno fijaron la ubicación del enclave romano- goce de $\tan$ buena salud en la historiografía eclesial y agregada precisamente cuando se empiezan a cuestionar sus excesos por la arqueología medieval ${ }^{20}$. Ésta es problemática que queda aplazada a excavaciones sistemáticas en el mismo solar en que Juan de Flores falsificó a su gusto. Antonio Malpica, historiador y arqueólogo me-

${ }^{19}$ Es significativo el empeño (coronado con éxito) del último arzobispo de Granada, recién promocionado a la sede primada, en recuperar para la ciudad (y para todo el ámbito granadino y andaluz, naturalmente) los libros plúmbeos que desde 1643 estaban en Roma; hecho muy trascendente en su opinión, pues están llamados a ser base del renacimiento del Sacromonte, postrado en la mayor miseria e inoperancia desde hace bastantes décadas (vid. $\mathrm{mi}$ «El bucle metahistórico»). Una muestra de esa atención interesada es el libro divulgativo (para consumo y halago local) del canónigo-historiador don Francisco Javier Martínez Medina, San Cecilio y San Gregorio, patronos de Granada, Granada, Comares, 2001, de un tono apologético muy calculado: pues, al reconocimiento inevitable de los fraudes, se siguen conclusiones como ésta: «...en un ámbito intermedio entre el mito y la historia hay que situar el complejo mensaje ideológico de los hallazgos, figura por otro lado muy frecuente en aquel tiempo, como fenómeno nacido de una profunda inquietud de los hombres por conocer algo importante para su existencia, de lo que no tiene noticias ciertas sino confusas informaciones. En estos casos la sociedad crea su propia historia al margen de cualquier influencia de la crítica» (p. 166). O como ésta otra, parágrafo de cierre del libro: «Cuando después de cuatro siglos los cristianos granadinos de comienzos del siglo XXI, mucho más críticos para el fenómeno religioso que los que nos precedieron, seguimos subiendo a principios de febrero al Sacromonte, no adoramos un mito ni caminamos hacia un lugar falsario inventado, sino que reafirmamos nuestra fe fundamentada en la certeza histórica de que el primer obispo y fundador de la antigua iglesia de Iliberri, cuyo nombre, que no hay dificultad en admitir como auténtico, no es otro que san Cecilio, y que como tal y junto a san Gregorio reciben desde la Edad Moderna culto en calidad de patronos de Granada» (p. 168). Etcétera, etcétera.

20 Vid. Malpica Cuello, A., Granada, ciudad islámica. Mitos y realidades, Granada, Azukaría Mediterránea, 2000; y en sentido opuesto, Orfila, M. y Sotomayor, M., «Granada, también íbero-romana», El Fingidor, 11 (enero-marzo 2001), 6-7. 
dievalista muy activo, en recentísima salida, escribe: «Sobre las actuaciones del P. Flores se ha llegado a escribir incluso una monografía (Sotomayor, $1988^{21}$ ). Pero nunca ha sido aclarado el objetivo principal que perseguía; sencillamente mostrar la gloriosa historia romana y, por ende, en combinación con el 'asunto del Sacromonte', cristiana y martirial»; y más adelante, tras advertir sobre la preferencia por los datos de fuentes no arqueológicas, por más que puedan ser dudosas, señala cómo «por ahora sólo podemos movernos en un terreno difícil, gracias al deseo manifiesto de muchos intelectuales e investigadores que no pretenden que la historia sea la ciencia que debe ser y se sienten más cómodos en una mitología creada a lo largo de los siglos por múltiples intereses» ${ }^{22}$. Es comprensible que, en su momento (y bajo acusación de anacronismo y desconocimiento histórico), fuera rechazada la crítica al arzobispo Castro y sus seguidores en relación con la instrumentalización de los martirios alpujarreños de 1568 , es decir, del intento de debelar un «programa» recristianizador recurrente, que, iniciado por el décimo arzobispo de Granada llega hasta nuestros días ${ }^{23}$.

En materias como la de los fraudes granadinos no cabe la presunción de inocencia en los olvidos u omisiones. Orillar autores incómodos o trabajos inconvenientes para el discurso propio es artimaña pueril por demasiado utilizada; más sutil es el silenciamiento de alguna temática que pueda dejar en evidencia la inanidad del discurso. Me he referido antes a la elusión de la cuestión de los defensorios del XVIII; pero es mucho más grave la postergación por décadas del estudio del paradigma contrarreformista granadino, consolidado, si no nacido, al amparo de Pedro de Castro y, en gran medida, fundamentado en los

${ }^{21}$ Alude al libro, antes citado, Cultura y picaresca; un hábil vaciado de la Razón del juicio..., de 1781, con alguna documentación complementaria inédita de ese juicio que se conserva en el Archivo de la Real Cancillería de Granada.

${ }_{22}$ «Acerca de la ciudad de Granada y sus orígenes», en Barrios Rozúa, J. M., ed., El Albaicín. Paraíso cerrado, conflicto urbano, Granada, Diputación (Centro de Investigaciones Etnológicas Ángel Ganivet), 2003, 14.

${ }^{23}$ Vid. Sotomayor, M., «Introducción» a Justino Antolínez de Burgos, Historia eclesiástica. Una réplica, en Barrios Aguilera, M. y Sánchez Ramos, V., Martirios y mentalidad martirial, 15-18. Es igualmente de notar que el mismo autor reproduzca un artículo de 1995-1996 (publicado originariamente en el Boletín de la Real Academia de Bellas Artes de Granada, 5, 61-96, «Fraude arqueológico y entusiasmo religioso en Granada») en el compilatorio Discipulos de la Historia. Estudios sobre cristianismo, Granada, Universidad, 2002, pp. 323-365, sin hacerse el más mínimo eco de lo publicado en los últimos seis años. 
contenidos plúmbeos, merced a una hábil y eficacísima paradoja instrumentada por el décimo prelado de la sede granatense. Es claro que la consideración de esta materia capital - auténtica cuestión de cuestiones-, implica redimensionar la temática que la antecede y la causa, es decir, las invenciones de la Torre Turpiana y de Valparaíso y de las acciones laminaria y antilaminaria derivadas de ellas. Consecuentemente, obliga a la relectura, a la revisión, de toda la literatura plúmbea y del largo rosario de hechos que suscitan los hallazgos. La necesidad del estudio de ese paradigma ha sido puesta sobre el tapete, velis nolis; $\mathrm{y}$, aunque sea de forma prospectiva, se ha insinuado alguno de sus elementos ${ }^{24}$. De ahí su inexcusabilidad.

Ahora bien, si el ejercicio de revisión es siempre sano, en algún caso puede ser tan interesado como los olvidos u omisiones, tratándose de temas ideológicamente sensibles como el que nos ocupa. En un artículo recentísimo se nos dice, de forma indubitada, que los libros plúmbeos, contra lo comúnmente aceptado, no son sólo obra de moriscos irredentos - es decir, de los Miguel de Luna y Alonso del Castillo y otros moriscos más encumbrados que estaban detrás y les transmitieron el tesoro tradicional de la vindicación ${ }^{25}$-, sino que responden a un «ambicioso proyecto» concebido por un «grupo de moriscos y cristianos viejos», cuyas intenciones son, y seguirán siendo seguramente, insondables: «Lejos de ser sólo una fabulación netamente morisca en sus inventores y en sus contenidos ideológicos, los libros plúmbeos tienen en su base las tradiciones medievales cristianas, la teología católica y la problemática político-religiosa de la España moderna; en su gestación también participaron activamente pensadores de marcado corte contrarreformista» ${ }^{26}$. Debe quedar cla-

${ }^{24}$ En mi aportación congresual «El Reino de Granada en la época de Felipe II a una nueva luz. De la cuestión morisca al paradigma contrarreformista...», 1998, hablo explícitamente del paradigma granadino asociado indisolublemente a Pedro de Castro. Antes, en 1993, en el ensayo introductorio al libro sobre los martirios de las Alpujarras, ya había advertido del «programa recristianizador» de Castro y de la instrumentalización de aquellas muertes en tal dirección. Estas ideas las he reiterado en otras publicaciones posteriores - vid. supra - y las he resumido dentro de un discurso más amplio en mi libro Granada morisca, la convivencia negada, capítulos 16 y 17 y epílogo. Los trabajos recentísimos de A. K. Harris y J. Calatrava, arriba citados, son muy significativas muestras de esta aspiración.

25 Puede verse, Rubiera Mata, M. ${ }^{\mathbf{a}}$ J., «La familia morisca de los Muley Fez».

${ }^{26}$ Martínez Medina, F. J.,«Los hallazgos del Sacromonte a la luz de la historia de la Iglesia y de la teología católica», Al-Qantara, XXIII, fasc. 2 (2002), 437-476, citas en 475. El subrayado de la cita (que es el resumen del artículo) es mío. 
ro que estas categóricas conclusiones no las basa el autor en ningún dato nuevo, ni archivístico ni bibliográfico; es fruto del análisis hermenéutico de los textos plúmbeos ${ }^{27}$. Va mucho más allá de la afirmación aceptable de que los realizadores de la superchería, inmersos en la sociedad viejocristiana, fueran moriscos conocedores de su religión, de su teología y aun dominadores de sus intríngulis. Es claro que eleva a verdad categórica la anotación de Ignacio de las Casas de no considerar los libros plúmbeos obra de moriscos, seguramente hecha con criterios políticos en su circunstancia, dentro de la «crudísima guerra» que libraba ${ }^{28}$. La lección que, en mi opinión, se deriva de esa conclusión novedosa no creo que sea difícil de adivinar: la responsabilidad falsaria de Castro queda aligerada, la paradoja se desactiva y el paradigma contrarreformista se legitima en las raíces cristianas de los plúmbeos...

Ni que decir tiene que hemos de alinearnos con quienes sostienen opiniones menos dudosas, sin cerrar las puertas a interpretaciones distintas de las tradicionales. Dice Gaspar Morocho: «Es muy probable que los falsificadores de los plomos tuvieran presente, además del Alcorán y de la literatura de los teólogos islámicos, algunos apócrifos de las Iglesias de Oriente, a través de recensiones árabes como deja sobreentender el P. Ignacio de las Casas». No es inverosímil que detrás de Castillo y Luna pudiera haber otros «personajes de mayor monta»: «Estos instigadores preparaban un cebo maléfico y filtro envenenado en el cual picaría Felipe II y los enemigos de la Princesa de Éboli y del secretario Antonio Pérez. Pero en el estudio de la documentación del Sacromonte no he logrado ver confirmada esta hipótesis, que a priori no debe excluirse» ${ }^{29}$. Por su parte, Rafael Benítez, siguiendo el hilo de los escritos de Ignacio de las Casas, franquea la idea de que «en los libros plúmbeos, más que pretenderse un sincretismo integrador entre los dos credos, como defiende la interpretación tradicional, nos encontraríamos ante el intento de un grupo de moriscos cultos para reanimar a sus correligionarios con una esperanza mesiánica» ${ }^{30}$.

${ }^{27}$ Realizado sobre la versión del marqués de Estepa, en publicación que en su momento hiciera M. J. Hagerty: Los libros plúmbeos.

28 Vid. R. Benítez Sánchez-Blanco, «De Pablo a Saulo», 434-435.

29 «Estudio introductorio del discurso», arriba citado, 184, 188-193.

30 «Mesianismo y milenarismo morisco», en prensa. 


\section{Dramatis personae}

Tres son, pues, los personajes principales de esta historia singular: el arzobispo Pedro de Castro, el gran sostenedor de los hallazgos sacromontanos; el jesuita morisco Ignacio de las Casas, tenaz refutador de los mismos; Luis Francisco de Viana, papelista del siglo XVIII, que toma a su cargo la tacha y descrédito de la memoria de Las Casas por cuenta del fundador carismático. Los dos primeros, protagonistas genuinos de unos hechos verdaderamente raros, personalidades ricas que se conocieron y que pusieron todas sus armas por vencer una guerra en la que habían empeñado energías, saberes y prestigios legítimamente ganados en otros campos menos dudosos. El tercero, canónigo sacromontano, fanático albacea, en la distancia de siglo y medio de su patrón carismático, de quien no quedó a la zaga en fanatismo ni en determinación. Viana es pieza clave en el anudamiento del espíritu sacromontano, como medio de conservar para la posteridad el legado castriano; se nos aparece, en fin, como síntesis, tardía pero cierta, de toda la actividad laminaria. Sin su aportación es inexplicable el Sacromonte que conocemos, la prolongada permanencia en el tiempo de su dudoso mensaje y la influencia en la configuración del imaginario granadino.

\section{a) El arzobispo Pedro de Castro, una personalidad contradictoria}

Aun faltando la biografía moderna que un personaje tan notable merece, los principales rasgos de la personalidad del arzobispo Castro y su acción plural son suficientemente conocidos, pues el atractivo de sus invenciones y fundaciones ha exigido un acercamiento a la persona que ha permitido el trazo de un perfil biográfico suficiente ${ }^{31} \mathrm{Ni}$ siquiera el hecho de que la mayor parte de las noticias originarias proceda de apologistas y, en menor medida, de detractores, enturbia ese conocimiento. Ahí está el Mistico ramillete de Heredia Barnuevo (1741): pese al indisimulado carácter hagiográfico es una verdadera

31 Vid. mi ensayo «Don Pedro de Castro y el Sacromonte de Granada en el Mistico ramillete de Heredia Barnuevo», que es estudio preliminar a Diego Nicolás de Heredia Barnuevo, Místico ramillete. Vida de don Pedro de Castro, fundador del Sacromonte, Granada, Universidad, 1998 (ed. facsímil de la de ${ }^{2} 1863$, en la Col. Archivum), VII-LXXIV más álbum iconográfico; perfil biográfico, IX-XXVI. 
cantera de informaciones, que, leídas con óptica crítica - no por casualidad lo consideramos el tercer gran defensorio del siglo XVIII; vid. infra-, conforman con mucho la más completa biografía del décimo arzobispo de Granada, de su personalidad, obra, aspiraciones y leyenda.

Dado que la faceta laminaria del prelado es de sobra conocida, pues se ha presentado hasta la saciedad en multitud de contextos - arriba se hace referencia a la amplia bibliografía que ha suscitado y sigue suscitando-, huelga traer aquí aunque sea un resumen mínimo; sin embargo, el hecho de que haya oscurecido otras ricas manifestaciones de su actividad, hace conveniente dejar una noticia esquemática, pero contrastada, del itinerario biográfico del personaje.

Don Pedro de Castro, Vaca (o Cabeza de Vaca) y Quiñones nació en Roa, obispado de Osma, en la actual provincia de Burgos, el 24 de mayo de 1534. Era hijo de don Cristóbal Vaca de Castro, notable personaje que ostentó cargos del mayor rango, entre ellos, el de consejero y eventual presidente del Supremo y Real Consejo de Castilla y capitán general y gobernador del Perú, y de doña Magdalena Quiñones y Osorio, emparentada con rancias ramas de la nobleza castellano-leonesa. Tras realizar estudios en Valladolid y Salamanca (Filosofía, Hebreo y Griego; Derechos Civil y Canónico), que le granjearon prestigio, aplicó sus conocimientos en la defensa del honor de su padre, acusado de fraude al fisco en su actuación americana. Antes de acceder al solio granadino, fue arcediano de Saldaña y ejerció en Granada el cargo de visitador de la Capilla Real, del Colegio Real y de la Universidad. Luego, fue nombrado oidor de la Chancillería de Granada (que no sirvió) y ocupó la presidencia, sucesivamente, de esta institución (1578-1583) y de la de Valladolid. En 1588 obtiene el grado de doctor en Sagrados Cánones en la Universidad de Valladolid.

Tras servir los obispados de Tarragona y Calahorra, es nombrado arzobispo de Granada el 6 de diciembre de 1589, sede de la que toma posesión el 15 de abril de 1590. Después de un pontificado granadino de veinte largos y densos años plenos de trabajos y avatares, el 5 de julio de 1610 es designado arzobispo de Sevilla (tras declinar la sede compostelana), donde ejercerá su pontificado hasta su muerte en aquella capital, el 20 de diciembre de 1623. En 1626, sus restos son trasladados y sepultados en la Abadía del Sacromonte, donde permanecen junto a los de sus padres y hermanos. 
Hombre de fuerte personalidad y de incontenible energía, afrontó en su largo pontificado de 33 años, en las diócesis de Granada y Sevilla, las mayores responsabilidades con singular entrega, en muy diversas facetas. Como reformador social y de acendrado espíritu caritativo (persecución de la prostitución, fundación de un colegio de niñas pobres, lucha contra las costumbres indecorosas, supresión de las representaciones teatrales...); como gobernante eclesiástico (visitas pastorales a todas las tierras de su archidiócesis, reformación del clero, dispensa de apoyo y busca de consejo de la Compañía de Jesús, de cuyas energías sacó beneficiosas enseñanzas, promoción de las misiones, mantenimiento e incremento del patrimonio eclesiástico, en una región que todavía padecía las secuelas de destrucción de la guerra de los moriscos...); como defensor de la jurisdicción eclesiástica frente a otros poderes, incluida la Corona, siendo como era decidido colaborador en la implantación de un catolicismo de Estado - guardó gran fidelidad a Felipe II, de quien se dice «hechura», siendo correspondido; también a Felipe III, cuyo reinado completo vivió-; como promotor incansable del Concepcionismo desde su sede sevillana, pero con virtualidad expansiva para todo el suelo ibérico, etcétera. Con semejante currículum, nada debe extrañar que su más cualificado hagiógrafo, del XVIII, Diego Nicolás de Heredia Barnuevo, lo llamara «Ambrosio de Granada, segundo Isidoro de Sevilla, y segundo Ildefonso de España, Espejo de Juezes Seculares, y exemplar de Eclesiásticos Pastores».

\section{b) El verdadero Ignacio de las Casas}

Mucho menos conocido que su opositor, el padre Ignacio de las Casas necesita de una mayor atención: fue jesuita destacado en la evangelización pacífica o "por medios suaves» ${ }^{32}$ de los moriscos. Había nacido mediado el siglo XVI en la ciudad de Granada y murió en 1608, justamente cuando estaba próximo a promulgarse el decreto de expulsión de todas la tierras de la Monarquía hispana. Es uno de los pocos moriscos jesuitas, pues, en 1593, la Quinta Congregación

32 No fue ciertamente el único. Vid. Márquez Villanueva, F., El problema morisco, 121-122. Para el Reino de Granada, mi Granada morisca, la convivencia negada, 301-322. 
General decretó prohibir la admisión en la compañía de descendientes de judíos o de moros ${ }^{33}$. Se formó en los colegios de la orden de Montilla, Córdoba y Roma. En esta ciudad pronunció sus votos en 1572 . Fue fruto de la casa de doctrina del Albaicín (fundada en esa morería granadina en 1559 y clausurada diez años después tras el levantamiento morisco), en la que se educó entre los años 1562 y 1567 , y de donde pasó al colegio de Montilla. Cuando se produjo el alzamiento de los moriscos de Granada (en las vísperas de la Navidad de 1568), estaba en fase de formación y alejado de la tierra natal, por lo que es difícil medir el impacto que los hechos pudieron tener en su conciencia; debió perturbarlo la apostasía y huida a Berbería de su hermano, que hizo que el general Aquaviva lo llamara a Roma, en 1581, para apartarlo del posible escándalo. Poco después, partió en una embajada a Oriente (1583-1584) dispuesta por el papa Gregorio XIII, que -es un dato de gran interés - «le permitió entrar en contacto con el abigarrado mundo de creencias: cristianos maronitas, melquitas, judíos sefardíes, renegados, musulmanes... Es una experiencia que recuerda en varios de sus escritos y que va a influir decisivamente en su interpretación de los libros plúmbeos»» ${ }^{34}$.

He aquí una ponderada valoración de Ignacio de las Casas:

\begin{abstract}
De salud enfermiza, padecía una afección asmática; hay indicios para pensar que era propenso a los escrúpulos, y su carácter colérico y melancólico parece que se fue agudizando con la edad. De buen juicio, ingenio y prudencia, era buen obrero y misionero con mediano talento para predicar a la gente común y era muy bueno para tener juntas y congregaciones con esta clase de personas. Por donde quiera que pasó fundó congregaciones para artesanos y oficiales: Florencia, Valencia, Segovia, Ávila ${ }^{35}$.
\end{abstract}

Si el apego al trabajo con los menos privilegiados fue un rasgo definitorio de su dimensión pastoral, no lo fue menos la actitud ante el problema de la asimilación de sus hermanos de raza, siempre consecuente con su formación y origen. Como hiciera en Sevilla el padre Juan de Albotodo - morisco, jesuita y maestro suyo en la casa de la doctrina de Granada-, Las Casas, prosiguiendo la pauta marcada en la primera es-

33 Según el decreto 52. La limpieza de sangre se convertiría en un elemento esencial de la identidad jesuítica, en conflicto con el pensamiento del fundador. Vid. Bangert, W. V., S. I., Historia de la Compañia de Jesús, Santander, Sal Terrae, 1981, 132.

34 Benítez Sánchez-Blanco, R., «De Pablo a Saulo», 406.

35 Medina, F. de B. de, «La Compañía de Jesús», 7. 
tancia en Valencia (1587-1590), desarrolló una intensa labor de apostolado, defensa y auxilio de los hermanos granadinos transterrados al solar castellano en las ciudades donde estuvo destinado (Valladolid, 1596; Ávila, 1598), valiéndose siempre de la lengua árabe. Lo que no debe confundirse con cualquier veleidad de complacencia con los islamizantes, pues fue muy duro en la condena de esta inadmisible apostasía desde su cristianismo integral y militante. Youssef El Alaoui sintetiza con precisión esta disyuntiva intelectual y vital:

\begin{abstract}
A la lectura de sus memoriales sentimos un desgarro, una lucha interna entre sus convicciones cristianas y sus orígenes porque sufría al ver a su pueblo despreciado por los cristianos viejos, por la Corona y por la Iglesia a la que pertenecía. En su «Información» preguntaba: "¿qué mayor infamia tienen éstos que los demás gentiles o hijos de hereges o que los descendientes del judaismo en estas partes?». Su atracción por la cultura musulmana podía parecer sospechosa, pero Ignacio de las Casas rechazaba el Islam y si se interesaba por la cultura musulmana era para convertir a los moriscos; sus proyectos de expansión del cristianismo en detrimento del Islam lo demuestran ${ }^{36}$.
\end{abstract}

Estando destinado en la Inquisición de Valencia (1602-1604), se aplicó con celo a luchar contra la expulsión de los moriscos, mediante la redacción de enérgicos memoriales, por el tiempo en que insistía en la refutación de los libros plúmbeos granadinos, y cuando el patriarca Juan de Ribera aconsejaba lo contrario al rey. Redobló su acción desde 1604, remitiendo sus escritos a las personalidades e instancias de Madrid y Roma, donde conservaba antiguas amistades muy caracterizadas, como el cardenal Bellarmino, sin inhibirse ante el rey Felipe III y los papas Clemente VIII y Paulo V. El padre Francisco de Borja de Medina explica muy bien la postura del jesuita morisco:

Casas exponía las causas de la situación a que había llegado la cuestión morisca, defendía el derecho de los moriscos a ser evangelizados en su propia lengua de modo conveniente y afirmaba que nada de cuanto se había hecho había dado resultado porque los métodos no habían sido los adecuados. No podía abandonarse a los moriscos ni condenarlos como culpables del fracaso evangelizador ${ }^{37}$.

La opinión del jesuita morisco era contraria a la de Juan de Ribera, despeñado ya por la pendiente de la opción de la expulsión ${ }^{38}$; influía

36 «Ignacio de las Casas», 338 (y passim).

37 «La Compañía de Jesús», 122.

38 Vid. Márquez Villanueva, F., «El nunc dimittis del patriarca Ribera», en El problema morisco, 196-318. 
en personalidades como el obispo de Segorbe, Feliciano de Figueroa, y el padre Antonio de Sobrino, notorios y cualificados defensores de la permanencia de los moriscos. Las Casas abundaba siempre en la profundización de los métodos de evangelización pacíficos y racionales, entre los que las escuelas de niños moriscos constituían pieza fundamental, así como la selección de un clero recto y competente, a ser posible buen dominador de la algarabía, «nervadura» de su argumentación. Cuando el general Aquaviva demandaba su ayuda de experto en las juntas que debatían la grave materia de la «solución final», es decir, de la expulsión de los moriscos de todas las tierras hispanas, muere Ignacio de las Casas. Corría el año $1608{ }^{39}$.

\section{c) Luis Francisco de Viana o el espíritu sacromontano}

Viana era natural de la ciudad de Granada, donde nació en 1689 40; fue colegial del Sacromonte desde el año 1704, y hasta 1711, siendo ordenado «in sacris a título de colegio». Hombre bien dotado para el estudio, siendo todavía colegial, antes de ser canónigo, leyó cátedra de Filosofía durante dos años, actividad que repitió luego como canónigo, supliendo asimismo las de Teología Escolástica y Moral. Ejerció también de rector del colegio de San Dionisio Areopagita, el de la fundación, durante cuatro años. Respondiendo fielmente al mandato del fundador, asistió muchos años a las misiones de esta casa ${ }^{41}$. Fue familiar del arzobispo de Granada, también sujeto sacromontano, don Martín de Ascargorta.

\footnotetext{
39 Ibidem, 120-125.

40 Como de los autores precedentes, la mayoría de las noticias de la vida de Viana proceden del Libro de entradas de los señores Abades y Canónigos del Sacromonte (ms. que se conserva en el archivo de la abadía), sv. «Luis Francisco de Viana». Z. Royo, en su Abades del Sacromonte, Anel, Granada, 1964, aporta alguna información complementaria. Todas las referencias han sido puntualmente consignadas en mi «Granada en escorzo», a donde remito.

${ }^{41}$ Recuérdese que la obligación de las misiones se establece en las constituciones del Sacromonte que firmó el propio Pedro de Castro, y que se cumplieron con encomiable entrega y dedicación hasta muy recientemente. Véase mi trabajo, «Las misiones en la sociedad posrepobladora: las del Sacromonte de Granada», en Barrios Aguilera, M. y Galán Sánchez, Á. (eds.), La Historia del Reino de Granada a debate, en prensa, y el Libro de misiones que se conserva manuscrito en el Archivo del Sacromonte. Viana no fue excepción.
} 
Fuera del Sacromonte, es capítulo destacado de la vida de Viana haber servido al poderoso cardenal Belluga ${ }^{42}$. Siendo éste obispo de Murcia, fue Viana «vno de los padres fundadores» de la Congregación de San Felipe Neri que en esa ciudad instituyó el cardenal. Fue luego secretario de esa congregación y prefecto del Oratorio. Al servicio del obispo de Jaén, ejerció también de coadjutor de la nueva fundación de la congregación en Baeza, donde predicó algún tiempo. Fue asimismo rector del colegio que ésta tenía en dicha localidad, y, al mismo tiempo, vicario de los dos conventos de esa filiación allí establecidos. Luego, ya canónigo del Sacromonte, desde 1716, el cardenal, obispo de Murcia, le ofreció varias «conveniencias», a las que se excusó diciendo que «preciaba más viuir en el Sacromonte en el ministerio más humilde que las mayores ínfulas de qualquier conveniencia en otra parte».

Concentrado ya en la abadía, el papel de Viana en la fundación fue de incesante actividad. Se ocupó de la administración de la hacienda de la institución durante años: arregló la contaduría, ajustó las memorias y patronatos y puso corrientes sus ventas; legajó la documentación, los cuantiosos manuscritos, del archivo secreto («de las quatro llaves»), poniéndola en orden, de manera que pudiese ser conocida y utilizada por sus compañeros Heredia Barnuevo, Pastor de los Cobos... En 1742, y por orden del cabildo sacromontano, trabajó el índice de todos los papeles del archivo secreto que se retenían en él, para remitirlo a la Inquisición; lo cual se hizo en efecto tras la aprobación del cabildo. Sirvió el trabajo para que se levantara «su general prohibición; lo que motiuó el sobreseimiento de el decreto que hauía publicado por su auto». Ese mismo año, el inquisidor general y arzobispo de Santiago, don Manuel Isidro Orozco Manrique de Lara, concedió a Viana «lizencia de leer qualesquiera libros» y la Real Academia de la Historia le nombró miembro honorario en reconocimiento de su labor erudita.

Desde comienzos de la década de los cuarenta toda la actividad de Viana se centra en la defensa de las invenciones y corolarios, convertidos en obsesión hasta su muerte. Son una veintena de años de una actividad febril en pro de la causa. El 30 de septiembre de 1760 es elegido abad, dignidad que había renunciado por dos veces en los años antecedentes. Muere el día primero de febrero de 1762.

${ }^{42}$ Hay biografia reciente de J. B. Vilar, El cardenal Luis Belluga, Granada, Comares, 2002. 
La preparación que le había supuesto el trabajo con los documentos del archivo secreto, su ordenación e indización, le proporcionó un conocimiento excepcional de toda la problemática que se venía arrastrando desde fines del siglo XVI. Conocía mejor que nadie las obras de su siglo, las de La Serna Cantoral, Pastor de los Cobos, Heredia Barnuevo, que en buena medida había inspirado y animado, así como el detalle de los esfuerzos vanos de su fundación ante la Santa Sede... Ello le permitió orientar los esfuerzos a enderezar los entuertos del siglo anterior, a recurrir a las máximas instancias civiles y religiosas..., pero también influir en otros campos aunque fueran tan dudosos como los fraudes de la Alcazaba.

Ya en el año 1740 había solicitado el jubileo para el día de San Cecilio, que concedió Benedicto XIV. Crecido por este éxito, escribió al cardenal Belluga suplicándole que promoviese la prescripción del decreto del año 1682, tanto en Roma como en Madrid. Logró que Belluga, a la sazón en Roma, se interesase, como se demuestra en el hecho de que se encomendara al canónigo romano monseñor Asemani la formación de un memorial a tal fin. Para su fundamentación pidió el cardenal la remisión a Roma de los escritos de Pastor de los Cobos, las Vindicias de Diego de la Serna y seis ejemplares del Mystico ramillete de Diego Nicolás de Heredia Barnuevo. No progresó esta gestión por causa de las guerras que entonces asolaban a Europa. Al poco, en 1743, murió el cardenal Belluga. Perdía Viana su principal mentor en el casi imposible asunto de la prescripción de la condena de Inocencio XI.

Siguió Viana en su defensa de la causa dentro y fuera del Sacromonte, como se demuestra en su apasionado alegato Statera veritatis, y en lo que resultó más práctico, pues lo coronó el éxito, «formar las preces» al papa Benedicto XIV para la confirmación de los estatutos de «doctrina y cáthedras de ambos derechos, historia y lenguas» (1753). Fue decisiva luego la intervención y la laboriosidad de Viana en la elaboración del catastro ordenado por el rey de las haciendas de la fundación y, posteriormente, en «la del concordato» de dar razón al rey de los canonicatos, capellanías, colegiaturas, patronatos y demás rentas de la fundación.

En diciembre de 1752 había sido nombrado por el cabildo titular de la cátedra de Historia Eclesiástica, nuevamente erigida y aprobada por la Santa Sede, y archivero de dicho cabildo, lo que le permitió redoblar su actividad vindicativa en los años inmediatos. Así, se afanó 
en el análisis de los manuscritos «de los errores que desde 1601 hasta 1750 se hauían estampado cerca de los dos hallazgos y artículos de religión y libros ilipulitano y turpiano», y redactó una Disertación Histórico-Crítica ${ }^{43}$, en la que respondía a los argumentos de los «émulos del Sacromonte». Estos trabajos los llevó a Roma el padre general de los dominicos, aliado voluntario y protector, y allí los defendió. Rebatió asimismo Viana un escrito opuesto del maestro jesuita padre Terreros, apoyándose en los testimonios de 75 correligionarios de éste que habían defendido los asuntos del Sacromonte antes y después de la bula inocentiana de 1682. Fundamentó, asimismo, la respuesta del letrado don Bruno Berruezo a las críticas vertidas por el maestro Sarmiento contra los fraudes de la Alcazaba. Finalmente, desde 1756, trabajó, junto con su compañero canónigo Joseph Juan de Laboraría, en el encargo regio de la Historia authéntica.

De la implicación de Viana en los fraudes de la Alcazaba de 1753 no hay duda. La Razón del juicio, editada en 1781, da cuenta clara de su papel de fautor intelectual. El hecho de haber muerto 15 años antes de producirse el fallo condenatorio de estos fraudes le libró seguramente de la tacha oficial, que sin embargo recayó en el realizador principal, Juan de Flores y Oddouz, y sus ayudadores, notoriamente en los clérigos Juan Velázquez de Echeverría y Cristóbal de Medina Conde, aunque seguramente no proporcionada a la magnitud del frau$\mathrm{de}^{44}$.

Del coautor, Joseph Juan de Laboraría, poco cabe decir aquí; su posición es mucho más discreta y su biografía escueta. Nacido en la localidad granadina de Güéjar Sierra fue colegial sacromontano y doctor en Teología por la Universidad de Granada, institución de la que luego fue catedrático; y, desde 1744, canónigo del Sacromonte. Fue asimismo rector del colegio de San Dionisio Areopagita y catedrático de la fundación abacial. Gozó de reputación de sabio y buen predicador. Murió en 1765, después de una vida caracterizada por «graves, penosos y dilatados accidentes» de salud.

\footnotetext{
${ }^{43}$ En el catálogo de Hagerty aparece con la signatura C.50, como libro publicado bajo pseudónimo de Cecilio Santos Urbina y Desfusa, Pamplona, 1752, 94 folios, y ms. C.56. Del libro se conservan dos ejemplares en la Biblioteca Nacional, Madrid.

${ }^{44}$ Vid. Razón del juicio; Sotomayor, M., Cultura y picaresca; también, los muy interesantes trabajos de J. Álvarez Barrientos y G. Mora Rodríguez arriba citados, con buen contraste documental.
} 


\section{Sobre los defensorios (1683-1781)}

Todos son conocidos, mas procede aquí una breve descripción y valoración, pues salvo en mis propios trabajos recientes no han sido estudiados específicamente - mucho menos dentro de un discurso unitario-; alguno ha sido utilizado por estudiosos modernos de forma más o menos episódica a la busca de este o aquel dato. El primero de ellos es Vindicias catholicas granatenses, de Diego de la Serna Cantoral ${ }^{45}$, publicado en Lyon, en 1706 . El título habla por sí mismo ${ }^{46}$; el lugar y la fecha de edición tienen su explicación: Lyon, «León de Francia», porque su publicación, contra corriente de la prohibición romana, no era del agrado de los censores de la época; lo que no significa que la circulación del libro en España fuera efectivamente perseguida, como demuestra el hecho de que hubo ejemplares en cuantos lugares debía haberlos, incluidas la corte de Madrid y la sede romana. La peripecia de su redacción es hoy bien conocida; la hemos reconstruido en sus detalles gracias a la propia información que proporciona la documentación del Archivo del Sacromonte: había comenzado tan pronto como se produjo la sentencia condenatoria de Roma de 1682. Se inició bajo el amparo del notable político y jurisconsulto Francisco Ramos del Manzano, y, muerto éste, en 1683, y por su recomendación, la continuó hasta su término La Serna Cantoral, a la sazón fiscal de la Real Chancillería de Granada, que quedó liberado de sus obligaciones para dedicarse a esa labor. Las Vindicias fue un empeño del cabildo sacromontano, pero en su financiación participó el Ayuntamiento de Granada, actuando incluso de garante. La obra es indigesta por su enorme extensión, por tipografía apretada, por su argumentación prolija y por su densidad factual y documental de no demasiado grata lectura. Es, con todo, el más concienzudo, sistemático y completo de todos los defensorios, un trabajo ingente, infi-

45 Vid. mi «Granada en escorzo...», 60-63.

${ }^{46}$ Aunque no aparece en la portada, sino en las cabezas de las páginas pares. El título de portada es: RELACION BREVE DE LAS RELIQUIAS QVE SE HALLARON EN LA CIVDAD DE Granada en vna torre antiquissima y en las Cauernas del Monte Illipulitano de Valparayso cerca de la ciudad: sacado del processo y aueriguaciones que cerca dello se hizieron. No se conservan muchos ejemplares de esta obra: en la biblioteca de la Universidad de Granada, Hospital Real, hay un volumen que contiene sólo la primera parte; en la de la Facultad de Teología de Granada, otro con las dos primeras partes; en la Biblioteca Nacional de Madrid y en la de la Real Academia de la Historia hay sendos ejemplares de la obra completa. 
nitamente superior en erudición y empaque académico a los que lo antecedieron y siguieron. Conecta y prolonga los memoriales anteriores a 1682. El concepcionismo ocupa lugar preferente en sus contenidos.

El siguiente defensorio del siglo XVIII se debe a Vicente Pastor de los Cobos (1686-1759) ${ }^{47}$, canónigo y asceta — se dice en el Libro de entradas... que murió en olor de santidad-, incansable papelista, quien, recluido entre las paredes de la abadía del Sacromonte, ajeno a toda llamada del exterior, escribió diversas obras, entre las que destaca Libro grande de Mística, que le acarreó algún disgusto con el Santo Oficio. Animado por su propio claustro compuso un copioso alegato, el resultante de la conjunción de dos manuscritos mamotréticos, Guerras cathólicas granatenses, escrito en 1730, y con título de fortuna, e Historia apologética sobre las ya postradas láminas granadinas, en 1738, que complementa al primero, hasta el punto de que bien puede considerarse su cuarta parte ${ }^{48}$. Ni uno ni otro gozaron del honor de la imprenta. La prolijidad y pesadez son características tan constantes que casi disuaden de su lectura. Tiene un tono más argumentativo y doctrinal, no exento de pretenciosidad teológica, que histórico; reitera datos pero sin demasiada precisión. La mayor virtud de los escritos de Pastor es marcar la temperatura ideológica existente en el Sacromonte y ejemplificar la vehemente determinación de que no se rompa la cadena vindicativa, contribuyendo a reforzar internamente la convicción en la causa.

En 1741 aparece publicado el tercero de los defensorios, el Mystico ramillete, de Diego Nicolás de Heredia Barnuevo (1700-1760) ${ }^{49}$. $\mathrm{Su}$ autor es canónigo como el anterior, aunque más extrovertido y mejor conocido, pues realizó otras funciones fuera del estrecho círculo

47 «Granada en escorzo...», 63-65.

48 De las Guerras... se conservan los siguientes manuscritos: C.10, C.11, C.13, C.14, C.15, C.17, del catálogo que hiciera M. J. Hágerty («Catálogo de manuscritos», en $L a$ Abadía del Sacromonte, 71-82); de la Historia apologética: C.12 y C. 16, de Ídem.

${ }^{49} \mathrm{Me}$ he ocupado de autor y obra en mi ensayo introductorio a la nueva edición del Mistico ramillete: «Don Pedro de Castro y el Sacromonte de Granada...», antes citado, passim, y especialmente, LXIII-LXXI. Un resumen de alguna amplitud, en «Granada en escorzo...», 66-67. El libro fue publicado por cuenta del canónigo Heredia Barnuevo en 1741; en 1863 se editó nuevamente, en Granada, aunque de forma selectiva, pues se suprimieron las flores, primera y tercera, reduciéndose el volumen al trabajo de Heredia Barnuevo, la biografia de Pedro de Castro, lo verdaderamente sustancial. Esta edición es la reproducida en la Col. Archivum en 1993. 
abacial. Con don Juan Francisco de la Cueva, presidente que fue de la Chancillería de Granada y miembro del Consejo de Castilla, viajó a Madrid y por él fue introducido en los medios literarios; gozó asimismo de la protección de don Manuel Isidro Manrique de Lara, inquisidor general y arzobispo de Santiago; fue académico en Granada y Madrid, y murió como abad de la colegial de Lorca. Este Mystico ramillete es básicamente una biografía del arzobispo Pedro de Castro, el fundador carismático, escrita en el más rotundo tono hagiográfico: no faltan los prodigios y milagros junto al relato rigurosamente cronológico de la actividad del prelado, tanto en Granada como en Sevilla. Planteada en principio como un defensorio convencional, parece ser que las dificultades de pasar el control de la censura, nada proclive a la sazón hacia esos productos, la vindicación formal de unos hechos reputados de falsos, le llevaron a solucionar la obra como biografía en forma de anales. Resultó ardid oportuno, pues eludiendo seguramente una nueva frustración, aireó el problema, trasladando el mensaje al foro público y, por supuesto, a las instancias más encumbradas de Granada, Madrid y Roma, donde hay noticia cierta de que llegaron ejemplares de la obra. Obra cuidadosamente documentada y clara, atizó el fuego de la irredención de la causa a través de la recreación de la vida ejemplar del venerable patrón, el arzobispo Castro.

Finalmente, la Historia authéntica ${ }^{50}$. Fernando VI encargó su redacción a los doctores Viana y Laboraría, por real orden de fecha 16 de septiembre de 1756, en que se ordenaba al abad se pusieran estos canónigos al trabajo «dispensándolos V. S. de la residencia, y teniéndolos presentes en el goce de sus Prebendas» todo el tiempo que estuvieren ocupados dada la importancia de la empresa. Era respuesta real, previa consulta a la Cámara Real, a la ya lejana petición cursada

50 «Granada en escorzo», 56-60. Los manuscritos del catálogo de Hagerty son C.52 y C.55. El mejor es este último que es por el que cito y el que he transcrito parcialmente en Chronica Nova, 29. Contiene la primera y la segunda parte, es decir, la totalidad de lo redactado. Su portadilla dice: Historia authéntica del hecho de los descubrimientos de Torre Turpiana y Monte Santo de Granada, desde el año de 1688 hasta el presente de 1756. Mandada trabajar por el rei nuestro señor don Fernando 6 (que Dios guarde) a los doctores Luis Francisco Viana y don Joseph Juan de Laboraría, canónigos de la Ynsigne Colegial de dicho Sacromonte, extramuros de la ciudad de Granada. Todo apunta a que fue el que trabajaron Viana y Medina Conde, y que fue el que sirvió de base para otros traslados, como el C.52 (sólo la segunda parte), que se hizo para uno de los coautores, Laboraría, tal como reza en leyenda que sigue a la portada y que lleva certificación del doctor Joseph Miguel Moreno. 
en 1743 por la abadía ${ }^{51}$, y entonces denegada, ante la solicitud que ahora hacía, en nombre del Sacromonte, don Diego Nicolás de Heredia Barnuevo, a la sazón abad de Lorca. El encargo se limitaba a la formación de una historia verdadera de las reliquias, sin entrar en los contenidos de los libros plúmbeos condenados en 1682 por Inocencio XI. La real orden se obedeció en cabildo sacromontano de 27 de septiembre de 1756 con la aceptación del nombramiento.

En seguida debió poner Viana mano a la obra, no se sabe con qué ayuda de Laboraría, pero seguro que con la muy diligente del falsario vocacional Cristóbal de Medina Conde ${ }^{52}$, su secretario, según se desprende de la nota preliminar a un traslado de la Historia authéntica, donde dice textualmente: «... y este traslado era del dicho doctor Lavoraría, quien lo hizo sacar para sí del vorrador que travajó dicho doctor Viana con su amanuense doctor don Christóval Conde...». Lo que sí es cierto es que la obra estaba concluida en sus dos primeras partes en 1758, tiempo relativamente corto dada su extensión y la magnitud del vaciado documental que contiene. Cabe aventurar que entre Viana y Conde hicieran el gasto y que la aportación de Laboraría fuera menor. En cualquier caso, el silencio de los papeles sobre la Laboraría antes y después de la redacción es bastante significativo, aparte de que el estilo induce a pensar que en su escritura se sumaban el entusiasmo fanático de Viana a la complacencia falsaria de su segundo. Es difícil saber a qué se debió la interrupción: Viana murió en 1762, pero no por ello cesó la vigencia del encargo, tal como se desprende del hecho de que en 1765 , poco antes de su propia muerte, Laboraría solicitaba al rey se le liberara de la obligación.

La estructura de la Historia authéntica se puede resumir muy brevemente: un total de 835 hojas, 1.670 folios, aunque generalmente de

\footnotetext{
51 Una interesante memoria a incorporar en futuro trabajo, pues su conocimiento me llega ahora, en una consulta del rey al inquisidor general, fechada en el Buen Retiro, a 26 de agosto de 1756, en relación con la licencia para escribir la Historia authéntica, pero que alude a la petición de 1743 con bastante detalle (Archivo General de Simancas, Gracia y Justicia, leg. 299; agradezco la noticia a Juan Luis Castellano).

${ }_{52}$ Un interesante perfil biográfico y valoración, en Camacho Martínez, R., «El canónigo Medina Conde», que es estudio introductorio a Medina Conde, C., La Catedral de Málaga, Málaga, Arguval, 1984, V-XXXII. No obstante, su amplia obra, la participación en los fraudes de la Alcazaba, su vinculación con Viana, su incontinencia publicística (en Málaga bajo el pseudónimo de Juan García de la Leña), aun cuando se le había prohibido escribir tras la condena, su proclividad a la controversia, con razón o sin ella..., hacen que Medina Conde merezca un estudio moderno extenso y matizado.
} 
escritura no demasiado densa, divididos en 48 capítulos de muy desigual extensión ( 12 de la primera parte y 36 de la segunda), subdivididos a su vez en 780 parágrafos, rigurosamente numerados (70 de la primera parte y 710 de la segunda), a lo que sumar un apéndice justificativo, literario y gráfico de 146 hojas más. En resumen, un cuantioso manuscrito, que quedó incompleto, pues el capítulo XXXVI de la segunda parte se acaba bruscamente tras un único parágrafo, el 710 , sin que lo anunciado en el título quede desvelado, ni el proceso de los hallazgos en modo alguno cerrado. Lo que es de todo punto evidente es que la obra no se concluyó, es decir, que la tercera parte prevista se quedó sin redactar, pues nada se conoce de ella, ni original ni copia. En un pasaje de la Historia authéntica se dice: «Los fundamentos con que unos encarecían la duda y otros sus respuestas las remitiremos con las demás que intervinieron hasta la sentencia de la calificación de las reliquias de este segundo hallazgo a la 3 . $^{\text {a }}$ parte de esta Historia quando llegue al año $1603 \ldots$.... Y más adelante: «Nótese este mandato para indemnizar el procedimiento del arzobispo que se referirá en la

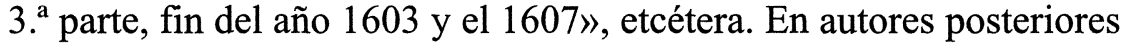
se dice que efectivamente lo conocido hoy es el total de cuanto se escribió.

La lectura de la Historia authéntica revela en seguida el afán documental de los autores, no sólo en el cuantioso apéndice, que es transcripción de documentos del archivo y reproducción dibujística fiel de las láminas plúmbeas y otros testimonios semejantes, sino a lo largo de toda la exposición en que se reproducen literalmente cartas, decretos, dictámenes y cuanta documentación del archivo sacromontano había disponible. Las anotaciones son rigurosas, se supone que de acuerdo con la legajación que en su momento dispuso el propio Viana. Menudean las notas con apoyaturas eruditas de escritores antiguos y padres de la Iglesia, en castellano y latín, pero no son las dominantes. Las remisiones al apéndice son sistemáticas y se recogen en los márgenes, no a pie de folio como la notas. Es, en fin, una obra mucho más digerible que los defensorios de La Serna y Pastor de los Cobos, a los que gana en agilidad argumentativa y en funcionalidad.

Sobre los aspectos ideológicos, es decir, el tono vindicativo y la evidente tendenciosidad y sesgo sostenido de la obra, sólo cabe subrayar lo dicho al referir la vida y la actuación del autor principal: sigue la tónica de los otros defensorios que le antecedieron, superándolos en apasionamiento, contundencia y acrimonia. Interesan mucho las 
consideraciones que al hilo de la exposición hacen los autores, aunque no hay que recurrir necesariamente a ellas para extraer las conclusiones de su implicación, pues en la narración de los hechos están manifestadas de forma meridiana. Sería redundancia extractar ejemplos, tanto más cuanto que su tenor, quizás llevado al extremo, se expresa elocuentemente en el análisis del caso que nos ocupa, el del padre Ignacio de las Casas.

\section{Las Casas en la Historia authéntica: La condenación de la memoria}

\section{a) Localización de los textos}

El suceso de Ignacio de las Casas se trata en cuatro capítulos de la segunda parte de la Historia authéntica:

- en el capítulo XXIV, dentro del relato general de los «progresos» de los hallazgos de la Torre Turpiana y Valparaíso hasta junio de $1596^{53}$;

- en el capítulo XXVII, el central en nuestro propósito, en que, de forma exclusiva, se relata la huida del padre Las Casas de Granada, la oposición cerrada a los hallazgos y cuantas maniobras realizó ante personajes de las cortes romana y española ${ }^{54}$;

- en el capítulo XXX, en que se insiste en las delaciones del jesuita morisco ya consumados todos los hallazgos, y su impronta en algún tratadista como el padre Jaime Bleda ${ }^{55}$;

- en el capítulo XXXV, en que se analizan con cierto detalle los efectos que las opiniones de Las Casas tienen en personalidades como los padres Jaime Bleda y Francisco Suárez, el cardenal Baronio, el padre Antonio Posevino y Spondano y el cardenal Bollando ${ }^{56}$.

${ }^{53} H A, 2 .^{a}$ parte, parágrafos $416-418,423$ y 425 ; fols. $632 \mathrm{r}-634 \mathrm{r}$.

54 Ibidem, parágrafos 513-553; fols. 704r-726r.

55 Ibidem, parágrafos 593-603; fols. 752v-760r.

${ }_{56}$ Ibidem, parágrafos 675-709; fols. 809v-835r. En el parágrafo 710, el primero del capítulo XXXVI, se corta el relato. Su título: «Demuéstrase el otro hombre que concurrió inprevenidamente a malquistar con pío dolo tres artículos de ambos hallazgos». Se refiere al jesuita Jerónimo Román de la Higuera, autor de famosos falsos cronicones. 
Publico los textos literalmente en otro lugar ${ }^{57}$; no obstante, aquí evocaré los hechos siguiendo el relato de Viana y Laboraría, con cierta generosidad en las citas textuales, por entender que son las que muestran más vivamente el tono de la condena de la memoria de Las Casas y el clima ideológico exaltado en que se produce, aun siendo encargo regio. Me atengo al orden dispuesto por los autores, pues es el cronológico y, por tanto, fácil de seguir en el intrincado laberinto de episodios que componen el suceso ${ }^{58}$. Aunque no se reproduzcan siempre las palabras en su literalidad, son los autores los que hablan a lo largo de todo el relato que sigue; de ellos son los datos, la interpretación y los juicios (a veces, terribles; aunque no más que los del propio arzobispo ${ }^{59}$ ) sobre las cartas y otros documentos del archivo del Sacromonte, documentos que se individúan. El enfrentamiento Castro-Las Casas ha sido recreado por otros tratadistas anteriormente; cabe aquí referirse a los apologistas setecentistas: La Serna Cantoral le dedica cumplida atención, aunque el relato, bien documentado, está lejos de la entidad y coherencia del de Viana y Laboraría; Pastor de los Cobos, más empeñado en la refutación teológica que en la narración de los hechos, es muy insuficiente y aun vago e inexacto; Heredia Barnuevo no hace ni una sola alusión a Las Casas, pues no debió entender procedente incluir elementos de controversia en una hagiografía ${ }^{60}$.

57 «Ignacio de las Casas y la polémica laminaria en la Historia authéntica de Viana y Laboraría (1756). El texto», Chronica Nova, 29, en prensa.

${ }^{58}$ No individuaré las referencias, que básicamente están señaladas en las notas antecedentes. Para una precisión textual específica, puede utilizarse la transcripción referida en la nota anterior de no poderse acceder a los manuscritos originales.

59 Opto por no subrayar las enormidades que se dicen sobre Las Casas; son sobreabundantes y no lo requieren, pues saltan a la vista.

${ }^{60}$ En los acercamientos posteriores, el más cuantioso y detenido es el de Zótico Royo Campos, quien le dedica un capítulo completo de su libro más legible (Reliquias martiriales, 1960, 102-114): aparte de incurrir en los peores usos de los apologistas de los siglos precedentes, presenta un relato incompleto, extracto, con toda probabilidad, del de Viana-Laboraría (que se cuida de no mencionar), por más que parezca haber hecho consulta directa de los legajos del archivo secreto (los mismos que registran en sus notas los autores de la Historia authéntica). C. Alonso y G. Morocho Gayo, con anterioridad a los estudios específicos sobre Las Casas que arriba se citan, han proporcionado muy interesantes informaciones, con apoyaturas archivísticas ciertas, dentro de discursos más generales sobre las láminas de Granada; pero no se han valido de la Historia authéntica. De los defensorios inéditos del XVIII, G. Morocho sí utiliza algún testimonio de Vicente Pastor de los Cobos, de cuyas Guerras cathólicas granatenses e Historia apologética se conservan copias manuscritas en la BRAH (completa de ésta: mss. 9/2229 y 9/2265; parcial de las Guerras: mss. 9/2266 y 9/2267). En otra ocasión habrá que cotejar los diversos tratamientos de los apologistas setecentista y anteriores. 
b) Niñez, ascensión y trabajos en Granada

Comienza el relato con la llegada por sorpresa de Las Casas a Granada: «Aparecióse en la ciudad a principio de 1597 el phenómeno de un yntérprete de cierta orden con fama de theológo, penitenciario de lenguas orientales en la romana curia». Portaba cartas de presentación de sus superiores de la orden jesuítica, donde se acreditaba el dominio de las lenguas. Con este aval, el arzobispo se confió plenamente y en seguida le mostró los originales de las láminas plúmbeas y copias y traducciones hasta entonces realizadas por otros intérpretes; concertó que se hospedara en la casa de su orden y que fuera a trabajar al palacio arzobispal por la mañana y por la tarde; en fin, le tomó el juramento preceptivo. Empezó el nuevo intérprete el trabajo en febrero.

Desde el principio mismo de su relato, los autores de la Historia authéntica dejan claro cuál va a ser el trato nada empático que darán a Ignacio de las Casas. La justificación de la atención y amplio espacio que se conceden al personaje es indicativa de su postura:

\footnotetext{
Estrañaráse mucho menos la menuda descripción echa y que se hará delante de las circunstancias de este religioso teniendo presente fue, después de poco más de un año que entendió en los trabajos que se referirán, el más deslumbrado perseguidor y ynfamador que tuvieron ellos mismos, y uno y otro hallazgo; pues hasta que, prófugo de su religión, echando sangre por la boca, falleció desgraciadamente en Ávila, en noviembre de 1608 , como se dirá en su lugar, no cesó de convatirlos, sembrando dentro y fuera del reino tal zizaña de falsías y siniestras suposiciones, que bastó a sofocar por casi un siglo el azendrado grano de la verdad, y aun a tenerlo hasta de presente sofocado por altos juicios de Dios, y en paraje incapaz de que se trille ni ventile.
}

La llegada de Las Casas, «yntérprete forastero», desanimó a los otros que ya trabajaban en esa labor; y es que, según el parecer de los relatores, en seguida se evidenció que en el «designio de su machinada idea» estaba apoderarse del negocio, «para hazer plausible su memoria en las cortes de Roma y España». Era, pues, necesario que los demás intérpretes, los «regnícolas», se fueran. Sin embargo, el arzobispo, aunque desconfiaba de las versiones producidas, pues su conocimiento del árabe era suficiente para detectar las deficiencias, no permitió que eso sucediera, les aumentó el sueldo y les dio una limosna. 
Ante la aceptación que los hallazgos iban tomando en Roma, en buena medida manifestada en sendas cartas de los auditores Francisco La Mata y Francisco Duarte (de fechas 25 y 26 de febrero de 1597), en que expresaban su apoyo al arzobispo, se avivaron «los intentos disfrazados del nuevo yntérprete» y el afán por ganarse su confianza. De manera que, sin haber tenido tiempo de sacar a limpio sus trabajos sobre el libro Fundamentum Ecclesiae, decidió entregar al arzobispo el borrador, donde además de una alabanza desmedida de sus contenidos, dejaba nota de las insuficiencias de conocimiento del intérprete: «esta voz es mui antigua, ésta no se precive, ésta es de otro ydioma peregrino, ésta no entiendo»; lo que llevó al prelado a devolvérselo, ordenándole que lo sacase a limpio, «pues hasta verla afinada, no podía hazer juicio de su pericia». «Frustrada la intención del disimulo, con que capcioso el penitenciario colocó la dedicatoria a lo último de aquella muestra prolongada de su imaginada habilidad y del alto concepto que avía formado del asunto», aceleró el ritmo de su trabajo, y al mes ya había sacado la versión a limpio, en romance y en latín, para presentarla al arzobispo.

El contenido de esta memoria es bien conocido ${ }^{61}$, sobre todo, porque sería una y otra vez esgrimido como prueba acusadora de las limitaciones de Las Casas para realizar su labor y de la falacia de su opinión, que de la noche a la mañana se tornó de alabanza exagerada, rayana en la adulación, a rechazo irracional.

Sirvió a los autores este primer episodio a modo de introducción para predisponer la lectura del resto. Es en el capítulo XXVII de la segunda parte donde despliegan la máxima batería de acusaciones, improperios e infundios para el descrédito de la memoria de Las Casas. Primero, fingiendo una biografía infamante, sin perdonar la niñez, de la que parten; luego, la huida vergonzante y las artimañas del jesuita morisco, despechado, para perjudicar la marcha del asunto. Ningún apologista ni anterior ni posterior ha sido tan explícito en el relato como Viana y Laboraría, aunque en otras obras no falten alusiones del mismo signo ${ }^{62}$. Ya el título del capítulo es de por sí expresivo del

${ }^{61}$ Lo reproduce la $H A$ íntegramente, empezando por la dedicatoria, aunque en la versión en limpio quedó al final. Diego de la Serna Cantoral lo incluye en sus Vindicias catholicas granatenses, parte primera, capítulo octavo, 76-79; antes, don Adán Centurión, marqués de Estepa, en su Información para la historia del Sacromonte..., de 1623.

${ }^{62}$ Sólo Z. Royo presenta un resumen, semejante en su sesgo tendencioso, pero lejos de la extensión, variedad temática y riqueza de detalles del de la Historia authéntica, a la que sigue por más que no la cite. Vid. supra. 
tono de su contenido: «Húiese de Granada el yntérprete penitenciario, descúbrese quién es y sus intentos, y refiérese su enconada oposición de ambos hallazgos».

Se reafirma en principio por los relatores ser este episodio el menos propalado en siglo y medio de toda la historia de Las Casas, siendo como es enormemente significativo para entender el paso del rendido elogio de los plúmbeos a la condena acérrima. Por eso será razón dar luz «puntualmente de quién fue este raro hombre»; lo que contribuirá a «ver claro el camino de la contradición» $\mathrm{y}$, también, a evitar que «vacile en su creencia el más advertido crítico». Y a fe que dan sobrada cuenta, aduciendo una carta escrita desde Ávila, de fecha 3 de enero de 1599 , por quien lo conoció y trató en Granada cuando era niño:

\footnotetext{
Nació en Granada por los años mil quinientos y quarenta Lope Yáñez (éste fue su primer nombre), de pres de nación moriscos de este reino. Aplicóle con gran calor el mudéjar su padre desde niño a las primeras letras, ansioso de que le aiudase después en su exercicio de solicitador. Costóle su educación en leer y escribir y la gramática no pocas desazones, porque desde luego descubrió Lepillo (que así le llamaban sus contemporáneos) un genio tan arrojado y travieso que lebantó aun siendo muchacho un testimonio tal a su madre, que la huviese muerto el marido si Dios no hubiera proveído el remedio. Nada escarmentado con esto, el temerario mozuelo lebantó otro poco después a un vezino suio de que se havía hallado un thesoro, y lo vistió con tal arte en la delación, que, a no aver probado el ynozente la quartada el tiempo en que se puso el hallazgo, le huvieran dado irremediablemente tormento.
}

Según los relatores, esta conducta le ganó el aborrecimiento de sus padres y el desprecio de su hermano mayor. Cumplidos ya los veinte años, y sin oficio, «pensó presentar le admitiesen por coadjutor lego aiudante de sacristán en el colegio de la Compañía de Jesús recién fundado en su patria». Y lo logró

\begin{abstract}
por el santo zelo que tanto ardía en esta sagrada religión por aquel respecto de la conversión de esta gente, que la rezibía francamente en sus claustros por facilitársela por este medio, aunque poco después determinó que en todos los recibos se guardase inviolablemente el estatuto de limpieza de sangre.
\end{abstract}

Vistió la jerga de coadjutor en este colegio, en el año 1562, pero por poco tiempo, pues, alzados los moriscos en 1568, su hermano mayor, que era boticario, se pasó a Berbería y renegó, a lo que se unió que sus padres no dieron «buena quenta» de la fe de Cristo, el colegio 
lo despojó de la coadjutoría. «Avergonzado y corrido» se marchó Yáñez de Granada a Roma, donde no conocían el caso, y cambió su nombre por Las Casas. Allí, a la sombra de los padres jesuitas Turriano (de quien «supo grangearse la voluntad» ayudándole en la traducción que hacía entonces de los cánones árabes del concilio de Nicea) y Eliano, inició su medra, gracias a que «savía bien el ydioma árabe occidental y escribirlo con toda perfección». A la sombra de jesuitas tan eminentes, logró «Ygnacio (que éste fue el nombre que recibió en aquel colegio)» ordenarse de presbítero y exponerse de confesor.

En 1582 el padre Eliano fue enviado por Gregorio XIII a Oriente como legado, «en que le fue preciso llevar escrito en árabe el cathecismo». El erudito se hizo acompañar de Las Casas, sirviéndole de secretario en una legación que duró seis años. Regresaron ambos a Roma en febrero de 1588, y poco después, quebrantado de sus muchos trabajos y por el proceloso viaje, murió el padre Eliano, no sin antes dejar «recomendado a los padres más graves del colegio a su compañero amanuense, revestido ya del carácter de Penitenciario de las Naciones Orientales (gracia que le consiguió del pontífice por premio de averlo acompañado en su viaje)». De todo ello dio cuenta Las Casas a su antiguo amigo el racionero Tamarid; quien, a su vez, le informaba en carta de 20 de abril de 1589 del hallazgo de la Torre Turpiana, y de

las grandes disputas que avían sobrevenido cerca de la traducción de lo que se hallaba escrito en él en árabe, y, en fin, consultándole sobre la verdadera raíz de algunos vocablos árabes en que discordaba él de los demás yntérpretes.

Fue a raíz de estas informaciones - sigue puntualmente el relato - cuando Las Casas se vio asaltado por el pensamiento de «pasar a su patria y hazerse persona en la materia». (Parece ser que le empujaba también el hecho de que en Granada habían quedado los hijos de su hermano apóstata en situación menesterosa). Faltaba sólo la ocasión propicia, pues en principio

embarazábale el rubor de su fuga venir a este colegio; y, detenido en este grillete, esperó cauto se le ofreciese ocasión en que pudiese entrar en él tan reguardado de la obediencia y escolta de estimación, que no fracasase su fortuna en el escollo de algún desdoro público.

La oportunidad le vino dada por el descubrimiento de los «escritos opisthógrafos en árabe» producido en la colina de Valparaíso en 
1595. Cautamente, siempre según el decir de los relatores, Las Casas se había acercado a Gandía, donde predicaba, «pretestando nezesitaban sus accidentes de los aires patrios para restablecerse»; lo que aduciría nuevamente para acercarse más aún a Granada. Pasó a Cartagena y luego a Murcia, donde en 1596 fijó su residencia. Allí esperó la «ocasión que avía concebido tantos años antes», y que se le vino «rodada tan presto», pues el arzobispo buscaba fuera de España «yntérpretes-theólogos inteligentes de la lengua árabe» para realizar la versión de lo descubierto. Con la recomendación de su provincial por el conocimiento que tenía del árabe, Las Casas fue reclamado «con grande instancia». Y efectivamente, a principio de 1597 «Lope Yáñez» estaba en Granada:

que se congratulaban grandes y pequeños de sólo visitarle. Deslumbráronse unos con las ynfulas de penitenciario; otros, con el crédito de theólogo, perito en lenguas orientales; y todos, con la mudanza de nombre y apellido sobre veinte y cinco años de ausencia. Y así pudo hazer en cerca de año y medio el papel que hizo con el arzobispo.

Sucedió, sin embargo, que no logró,

ni con los prolixos escolios y paráphrasis que trabajó del primer libro, ni con la copiosa erudición de su exagerado parezer sobre la importancia del asumpto, verse dueño del negocio (que era toda su manía), rezelando incauto se la trasluciesen sus superiores.

Intentó afianzar su situación consiguiendo que el visitador, padre Fernando Lucero, le escribiera una carta desde Sevilla (17 de marzo de 1597) alentándolo al trabajo y que el provincial de Andalucía, padre Francisco Quesada, hiciera lo propio desde Baeza (julio de 1597). Mas no se conformó con esto, sino que quiso asegurarse la autorización de sus superiores para permanecer en ese negocio por cuanto tiempo fuera necesario, pues entre tanto habían aparecido otros libros (cuatro el 27 de agosto y otros el 4 de septiembre), «que hasta el presente eran todos catorze con los hallados antes». Obtuvo que el arzobispo escribiera al general Aquaviva, pues creía saber que recibiría fácilmente tan decisivo apoyo, dada la buena aceptación de los hallazgos en la corte romana:

Sabía éste bien sería faborable la respuesta del reverendísimo Claudio Aquaviva, porque le constaba el alto concepto que avía formado de ambos descubri- 
mientos desde que averiguó el famoso milagro que Dios obró en honor de estos santos mártires con el padre Melchor de San Juan y asimismo porque tenía aviso por sus confidentes en Roma de la nueva atestación que le avía dade de aquel portento y demás acaecidos los primeros sujetos que avían concurrido a aquella curia de estas probincias a la congregación general celebrada por este tiempo de asistente de la Corona, y de que avía sido concorde el informe que todos le avían echo de la grande expectación en que tenían a toda la nación estos hallazgos.

La respuesta de Aquaviva (Roma, 16 de enero de 1598), «sacudió el recelo de que lo removiesen con ningún pretesto de la ocupación en que estaba», con lo cual se afanó ahora en ganarse la voluntad del arzobispo para que le permitiese llevar a su aposento los plomos originales, su aspiración obsesiva desde entonces. Se resistió el arzobispo, pero le entregó dos copias y sus respectivas traducciones de los dos primeros libros, «que avían trabajado los yntérpretes más inteligentes». No le pareció a Las Casas suficiente, y reclamó todas las copias y versiones,

alegando su grande conocimiento del ydioma y la suma nezesidad que havía de reverlas y corregirlas, presumiendo contendrían errores e impropiedades de voces, como echura de hombres sin luzes de theología ni lección de padres.

El arzobispo, «adelantado ya en el estudio de la lengua árabe»y cada día más desconfiado de las versiones e interpretaciones hechas hasta ese momento,

así por el peregrino carácter y casi imperzeptible de sus ápizes y puntos, como por la suma antigüedad de sus dicciones árabes, syras, hebreas, chaldeas y griegas, que fundaban prudentemente su rezelo, [condescendió], atendiendo a este hijo de una religión tan grave y que tanto veneraba, y a la recomendación que tenía de su persona,

entregó a Las Casas (tras el preceptivo juramento de no rebelar ni un papel) todo cuanto los demás intérpretes habían trabajado, es decir, copias de los originales, escolios, paráfrasis y versiones.

Los relatores desvelan inmisericordes las ocultas razones del intérprete:

Por dos motibos usó Casas del ardid de esta 2. ${ }^{a}$ petición: uno, por acusar la ignorancia de sus compañeros y revajarlos del concepto, como lo executó, notando singularmente de ygnorantes a Miguel de Luna y a Diego de Vrrea, que eran los más afamados y de más nombre en la lección del carácter llamado salomónico entre todos los peritos árabes del reino; otro, y el principal, porque no acertando él a leer desde el principio los plomos originales, como se evidenció poco des- 
pués, en 15 de maio de 1598, por carezer del conocimiento del carácter salomónico, de figura estraña y diversa del usual árabe en el oriente, y, asimismo, porque siendo tan menudo y pequeño y él ya de crecida edad y de tan corta y cansada vista, que, aun aiudada de lente, con dificultad lo podía perfectamente discernir. Se avía valido desde que se infirió en el negocio de ir sacando, como quien perita, el renglón caráchter por caráchter, con todos sus ápizes; cotejábalos después con los copiados por los otros yntérpretes, y, últimamente, de sus versiones iva refiriendo el valor y potestad de cada letra. A costa de tan prolixo trabaxo, es constante avía echo los escolios, paráfrasis y traducción que referimos del primer plomo opistógrapho.

Así pudo avanzar Las Casas en su trabajo más fácilmente. Pero evidenciando en todo momento su ignorancia e insuficiencias, que los relatores pasaron a individuar «para hazer visible la maligna astucia de este yntérprete». Recogen cómo desde que llegó a Granada hasta junio de ese año de 1597 se empleó en "escolios, paráphrasis y esplicación palabra por palabra» del libro Fundamentum Ecclesiae; mediado junio, comenzó la versión latina «con escholios de una coluna, $\mathrm{y}$, en otra, la versión en castellano, escholiada también». Así, hasta fin de ese mes. Consideran los autores digno de notar, lo que es abundamiento de lo dicho, cómo al margen de los folios escribe de su puño y letra:

Estas palabras son dificultosísimas; no las alcanzo; sólo por antezedente y sonsiguiente colijo la mente del author [...] Dexo estas lacunas en blanco porque no penetro el significado genuino de las dicciones.

Los tres meses siguientes los ocupó Las Casas en el estudio del opistógrafo De esentia Dei y desde octubre a diciembre se ocupó en «verter y escoliar» el Sigilo de Salomón. En ambos reiteró sus advertencias de incapacidad. Remarcan los relatores:

Pero donde descubrió más su impericia fue en el opistógrapho de la historia del Mudo o Ylegible, pues en cada período se detubo a confirmar el significado de la voz que no alcanzó a entender (que fueron muchas) con las hebreas y griegas, con varios lugares de escritura, recatando aquí la cantinela, más que en otro trabajo, de no alcanzar la mente del author por la peregrina antigüedad del ydioma y dificultad de averiguar la dedución original de los vocablos.

Terminados los trabajos en esos opistógrafos, en 11 de marzo de 1598 , se empeñó en hacer lo propio con los dos de Divina potencia, «confesando a cada paso su ignorancia en las frequentes lacunas que 
dejó en esta obra», y, luego, hasta el 15 de mayo, «en que desapareció de este colegio», en la versión latina del opistógrafo de la Sentencia, que dejó inconclusa.

Ésta fue la labor del intérprete jesuita, seguida con puntualidad, que los autores se esmeran en definir con detalle y rigor cronológico, anotando siempre la fuente del archivo secreto en que se documentan. Aparte de revestir la historia de ropaje erudito, la descripción, que en alguna forma suspende la linealidad del relato, les sirve para subrayar con cansina reiteración las grandes carencias del intérprete.

Cumplido el objetivo, que es en realidad abundamiento y justificación pormenorizada de las descalificaciones que se vierten en el capítulo precedente, retoman los relatores «la serie de esta historia», recreando la nueva estratagema de Las Casas para conseguir su objetivo, que fue ponderar, en sendas cartas remitidas al arzobispo y a sus superiores, en abril de 1598, «la quiebra de su salud espiritual y corporal» producida por las madrugadas y trasnoches excesivos, consecuencia de tener que desplazarse a trabajar al palacio episcopal dos veces al día. Se registra la argumentación del intérprete de que, de seguir dedicando tan corto tiempo al trabajo, apenas unas cuatro horas diarias, no podría concluir la tarea en menos de seis u ocho años. A estas dificultades se añadía la incomodidad que le producía no poder hablar en libertad en el palacio por haber siempre gente presta a interpretar sus palabras de forma torcida, las peticiones incesantes de quienes le creían influyente en la voluntad de su mentor, el excesivo tráfago propio de la residencia episcopal..., cosas todas que le quitaban el sosiego exigido por un trabajo cuya dureza intrínseca casaba mal con la precariedad de su salud: «Mirando a mi poca salud, que con toda verdad es tan poca, que yo mismo me maravillo de que haia podido trabaxar tanto escriviendo, por ser tan contrario al pecho y asma...». Y finalizaba exponiendo la falsa situación en que se hallaba ante su propia orden al no desempeñar funciones de predicador y confesor, razón de ser de sus miembros, que le acortaba hasta de pedir la ropa que necesitaba. 


\section{c) Fuga de Granada y primeras maniobras contra las invenciones}

Interpretan los relatores estas cartas como fingimiento «maniaco» del intérprete para lograr su intento y se felicitan de que se hubieran escrito cuando «la noble familia del prelado havía traslucido quién era», por medio de un «moro ladino», esclavo antiguo del marqués de Mondéjar, que lo conocía desde su niñez, de un deudo del arzobispo llamado Campomanes y del secretario Muru. Así, pues, cuando Las Casas le intenta entregar un nuevo memorial sobre el asunto, el arzobispo estaba ya prevenido. Se retiró al convento de franciscanos recoletos de La Zubia, «y, con aquella rara penetración, prudencia y grande espera de que Nuestro Señor le avía dotado» se limitó a convidar al intérprete a comer al día siguiente en ese lugar, donde hablarían despacio de la materia.

Creyendo el intérprete que había conseguido su objetivo, y cuando se quedó a solas con el arzobispo, aventuró su propuesta, en forma de fea transacción:

\footnotetext{
Viendo Casas (quando más ciego) la ocasión que tanto tiempo avía deseado, desabrochó su pecho al príncipe y le dixo que, confiándole los plomos originales como le esponía en el memorial y condecorándole con la Corte de España para con la de Roma, era capaz de poner el negocio en las congregaciones de aquella santa curia en paraje que correspondiese el éxito a la espectación dél en que estaba toda la nación, pues conocía bien los peritos en lenguas que allí avía, que casi todos eran sus confesados y les devía alguna opinión para que subscriviesen a su dictamen.
}

El arzobispo oyó con aparente afabilidad la propuesta, pero le respondió que, para su seguridad y poder informar a la corte, necesitaba ver cómo leía los originales y como traducía «de repente». Sacó entonces de un cofrecito unos opistógrafos no vistos antes por Las Casas y se los puso delante, mandándole los leyera e interpretara. Los relatores se recrean en la escena:

Demudóse aquel hombre de repente, y, cubierto de un sudor frío, no acertó a articular palabra, siendo una scena bien para admirada viendo al prelado circunspecto esperando a oír la leción y versión de las ojas originales y al yntérprete penitenciario, temblando de rubor y confusión, retirarse de su presencia sin despedirse.

Luego, partió avergonzado a su colegio, donde llegó al anochecer; se encerró en su aposento, y, tomando los papeles que tenía, los divi- 
dió en tres legajos: uno, lo introdujo en una arquilla y lo cerró con llave; el segundo, lo dejó esparcido sobre el bufete; el tercero, lo dejó para llevarlo consigo. Mediante un confidente, entregó la arquilla al canónigo de Santiago, que había sido su hijo de confesión, con una misiva en que le pedía se la guardase con sigilo a buen recaudo hasta que se la enviase a pedir, porque se veía obligado, por su honor, a ausentarse de la ciudad. Al día siguiente, 15 de mayo de 1598, de madrugada, y sin ser visto, marchó el intérprete a Córdoba.

Ya en esa ciudad, y antes de que llegara una requisitoria del arzobispo, «cometió Casas un crimen no disimulable», que fue entregar al padre Luis Alcázar, que trabajaba en la Exposición del Apocalipsis, el opistógrafo Fundamentum Ecclesiae, por cuyo contenido estaba muy interesado. Violaba con ello el juramento in verbo sacerdotis que hiciera en el momento de su llegada a Granada. De esta forma se evidenciaba - siempre en la letra de los relatores - el propósito que abrigaba cuando se llevó la valija, «pues no pudo ser otro sino el de valerse de ellos para revelarlos quando y a quien le pareciere conveniente, como lo hizo hasta que murió». Con anterioridad, había filtrado a su superior de Andalucía, el padre Francisco de Quesada, contenidos de los hallazgos de Valparaíso, «agua turbia» de la que bebió el padre Pineda para sus comentarios a Job y Salomón:

\footnotetext{
Dedúcese también el cauce por donde se transmitieron al público tantos secretos que estaban recónditos en las versiones, $y$, asimismo, las inumerables inepcias de erradas narratibas del echo de este segundo descubrimiento como se dibulgaron y corrieron poco después estampadas dentro y fuera del reino, y aún se leen hasta oi impresas y recomendadas por regnícolas y estraños.
}

El provincial de Andalucía reconvino severamente a Las Casas por su conducta; le requisó los papeles y se los envió al arzobispo Castro; luego, lo despachó a Valladolid, en cuyo colegio había tenido antes residencia. Consiguió además que los papeles que había dejado esparcidos en el aposento de Granada fueran también a las manos del arzobispo, a quien informó asimismo de las gestiones que había hecho con sus superiores de Castilla y Madrid para que no se le consintiese acudir a ningún tribunal sobre el negocio, «pues en realidad no havía en qué reparar», y de cómo Las Casas no se sosegaba, por lo que había tenido que recurrir al general Aquaviva para que se lo mandase.

Resentido del tratamiento del provincial en Córdoba, que presumió efecto de los informes del arzobispo, y, enterado por sus confidentes de 
que en junio el papa iba a encomendar a éste, en su calidad de ordinario, la calificación de las reliquias, le escribió, el día 17 de ese mes, «una atrevida, prolongada, carta», amenazándolo con delatar el negocio a la Inquisición General y al rey si pasaba a la calificación. Le exponía «la trabazón, conexión y dependencia que las reliquias de los santos tenían con los libros» y otras particularidades, especialmente

la notable de que creía no ser los libros cosas de moros, y que, aunque esto lo tenía por mui cierto, por el mismo caso que se reputan por de tanta antigüedad como del primer siglo, no podía separarse el artículo de la calificación de las reliquias del otro de los libros.

Y concluía pidiendo respuesta a vuelta de correo y certificada, de que, de no atenderse su exigencia, se vería obligado a marchar a Madrid y «a hablar con esta verdad y claridad».

A la «disparada avilantez» de esta carta, respondió el arzobispo con otra, de fecha 12 de julio, «modestísima» - siempre en el decir de los relatores-, en la que invita al intérprete a revisar sus juicios sobre las láminas, pues pugnaban con el parecer de los demás, incluido el de su propia orden, que «lo sentirá mucho y tomaría ásperamente con razón». Descarta el arzobispo la posibilidad de hacer la calificación prontamente, pues hay peste, con lo que la gente no se mueve, y por eso había dejado de llamarla.

La respuesta del arzobispo, antes que contener a «este precipitado espíritu» lo irritó, exasperándolo grandemente; y, así, cumplió su amenaza: dio cuenta de su opinión en un extenso memorial a la Inquisición de Valladolid, para que a su vez lo remitiera a don Pedro Portocarrero, inquisidor general y obispo de Cuenca. Se valió sin duda en la redacción de los papeles que, «perjuro», había ocultado a la requisa de su provincial en Córdoba, dado que los que contenía la arquilla que había dejado en Granada no le llegaron hasta diciembre de ese año de 1598.

Antes de alcanzar este punto, Las Casas había desestimado la orden de su provincial, el padre Esteban de Ojeda, de no volver a hablar más del asunto. $\mathrm{Al}$ «perpetuo silencio» impuesto a su vez por la $\mathrm{Su}-$ prema, después de que fuera oído en Madrid, respondió quejándose al inquisidor general de no haber sido considerados sus fundamentos. Portocarrero lo invitó, en presencia del confesor Baltasar de Porreño y su secretario, a exponerlos de nuevo: Así, 
repitió todos sus argumentos, que no fueron otros que los que avía espuesto al consejo pleno de la general, y los mismos en que persistió hasta morir, cansando a todos los tribunales; $y$, en fin, los mismos que después de su muerte dexó por herencia a quantos amigos y confidentes los comunicó dentro y fuera del reino, por cuio medio consiguió que sobrevibiesen a él, como se verá, hasta el pontificado de Ynocencio XI.

No convenció al inquisidor general, quien tomó la resolución de enviarle de vuelta a su residencia, «mandándole con censuras no hablase de la materia»; mandato que le fue reiterado por su provincial, en carta de octubre de 1598:

Paréceme que, aviendo ya cumplido con los escrúpulos que tenía vuestra reverencia en el negocio del Sacromonte, pues los espuso en el tribunal que podía conozer de ellos, de razón estará ya satisfecho, y tendré yo justo título de mandarle, como lo hago por ésta, no trate ya más de ese negocio, ni hable con nadie de él; y, aunque entiendo debe estar en esta resolución, por aver entendido ser esta la voluntad del señor ynquisidor general y estos señores, como me lo han dicho; y también estoi cierto que en ello hará vuestra reverendísima una cosa mui grata a nuestro padre general y a todos los que somos la compañía, y me parece que vuestra reverendísima tiene obligación de hazerlo así, pues ya hablar en ello de aquí adelante no puede ser escrúpulo de conciencia habiéndolo depuesto.

En otra carta, de fecha 3 de noviembre de 1598, el inquisidor general expresa al arzobispo su buena disposición hacia el asunto y hacia su persona, animándolo a la calificación, pues en nada estimaba los argumentos del opositor. Sin embargo, no inhibieron a éste los mandatos de los inquisidores y de sus superiores de orden; antes al contrario, agraviado por lo que entendía desatención, dio cuenta al rey, al confesor real, al secretario, don Juan de Idiáquez, al arzobispo de Toledo, don García de Loaysa, y al nuncio. Luego, se retiró a Palencia a esperar. Allí le llegó la noticia de la muerte de Felipe II. A principios de 1599, remitió memoria a Felipe III, que se hallaba en Valencia esperando a la reina doña Margarita, y a su confesor. Intentaba por todos los medios que

el artículo de las reliquias no se dividiese ni se separase del de los libros, y que era ya notorio en el reino que la santidad de Clemente VIII, por su breve de primero de junio avía separado y dividido estos dos artículos.

Por su parte, el arzobispo se había encargado de prevenir al nuevo rey para contrarrestar los «siniestros» informes que le pudieran llegar, 
no obstante que lo consideraba instruido enteramente del negocio por haber empezado a despachar los asuntos de gobierno con su padre desde julio de 1597. Lo hizo en carta de fecha 15 de noviembre de 1598 , donde, además de afirmar el gran cuidado que siempre tuvo en lo de los hallazgos — «siempre he hecho oficio de fiscal»-, entre otras cosas informaba al rey de la actitud de Las Casas y del cambio experimentado que no entendía, pues, aparte haber estado desde el principio «mui contento y los estimaba con gran deboción», lo había tratado con la máxima consideración personal, hospedándolo en su casa. Escribe el arzobispo:

No sé qué disgusto tuvo, con que se determinó irse a Castilla sin darme quenta de su viaje; escrivióme desde Valladolid una carta como desafío, hablando de los libros e interpretación con poca consideración y cortesía, poniendo sospecha en algunas preposiciones mal entendidas y mal interpretadas por él mismo.

\section{Luego, suplica al rey que}

se sirba de mandar se tenga cuidado, si este padre acudiese a vuestra magestad (so color de buen zelo), sea examinado el fin que tiene de perturbar una cosa que aún no ha salido a la luz y es tan importante a los reinos de vuestra magestad y bien común de la Yglesia Cathólica; porque pretende quatro cosas sin fundamento ni razón, con las quales descubre su pasión y ánimo contradictorio.

Rebate, en fin, las contradicciones de Las Casas con palabras que merecen ser reproducidas, pues expresan claramente la endeblez argumentativa del arzobispo al reducirse a afear una vez más las actitudes del opositor, a señalar las circunstancias de la colaboración y los aspectos externos del trabajo. En ningún momento aborda el fondo de las cuestiones, por mucho que los relatores esgrimen las palabras con devota fruición:

Lo $1 .^{\circ}$, que en los libros ai errores y cosas sospechosas, como quiera que los que él ynterpretó y los demás han interpretado están censurados y aprobados por letrados y theólogos, hombres eminentes de ciencia y conciencia, así de mi cavildo como de la misma compañía y de todas las religiones de Granada; y si alguna cosa ha havido en que él ha reparado, bien save que en muchas a reparado interpretando, y que mirándolas con más cuidado ha confesado estaba el daño en su ignorancia y no en lo escrito en el libro; lo qual cada día sucede con los demás yntérpretes por ser la letra tan antigua y la materia tan alta, y su cuidado frágil, pues en algunas cláusulas el mismo padre tenía quatro y más interpretaciones con diferentes y contrarios sentidos; y así, determinarse por sólo su parezer y en ausencia a calificar cosa tan importante, en la qual su santidad y vuestra magestad 
han impuesto silencio y reservado para sí es cosa digna de reprehensión, y de que vuestra magestad buelva por esta causa hasta que esté acabada.

Lo $2 .^{\circ}$, dize que no se ha dado quenta a su santidad ni [a] vuestra magestad; so color de esto quiere indignar el ánimo y zelo santísimo de vuestra magestad, pues es notorio que acabada la interpretación y censura la embíe luego a vuestra magestad y después acá boi haciendo diligencia en la interpretación de los demás libros, y, en el ínterin, dando relación a vuestra magestad de todo lo que pasa.

Lo $3 .^{\circ}$, dize que no se puede proceder a la calificación de las reliquias hasta averiguar la verdad de los libros, por tener grande dependencia y unión lo uno con lo otro; en esto se ve quán poca noticia tiene el padre Ygnacio de este caso, que su santidad tiene dividido y separado el negocio de las reliquias de los libros; pues me dize por su breve que califica las reliquias y que la censura de los libros reserva para sí; y con la razón lo dize, porque estos tres santos obispos, que aquí padezieron, son canonizados y rezebidos en la Yglesia Cathólica primitiva; y así, el calificar estas reliquias no puede tener inconbeniente ni dependencia de los libros; los quales, si fueran falsos, su santidad los declarara por tales; y, antes de esto, indecencia sería hablar en ello, pues sólo su santidad es el que lo ha de declarar; y, aunque los libros sean de doctrina falsa, los santos ya dichos no pueden dexar de ser santos, pues la Yglesia no pudo errar en rezibirlos por tales.

Lo quarto, dize que ai nezesidad que vengan yntérpretes árabes cathólicos que ai en la provincia de los maronitas, para que, concurriendo el ser theólogos, éstos se verifiquen. Yo querría que todos los intérpretes quales convengan vinieren a interpretarlos y los gratificaría en quanto pudiere, pero, en el ínterin, no es justo vuestra magestad permita que el padre Ygnacio (que es el que por esta razón confiesa que ai falta de yntérpretes) censure con tanto atrevimiento tan injustamente la materia de los dichos libros sin averlos visto todos, ni la maior parte de ellos; y que el que a pocos días confesava que daría la vida por la verdad de ellos aia prevaricado sin fundamento ninguno, con peligro de un daño tan universal de la república de vuestra magestad...

De esta forma se cierra el capítulo XXVII, el principal de la condena de la memoria del intérprete antilaminario.

\section{d) Contumacia delatoria y contrarréplicas sacromontanas}

El capítulo XXX lleva este título: «Descúbrense otros dos libros, como los veinte prezedentes; ynsiste Casas en sus delaciones y el arzobispo, en poner en execución el último breve».

Los relatores advierten de que la aparición de dos nuevos libros en Valparaíso «incitó el espíritu de la arrabiada contradición de Casas» buscando todos los medios de que pudo valerse su «encono» para impedir que llegara la calificación. Se implicó en que se publicaran las razones de oposición de don Juan Bautista Pérez, obispo de Segorbe y 
antilaminario caracterizado, en un santoral que había dejado preparado antes de su muerte (producida el 8 de mayo de 1597); pero no lo consiguió, pues su sucesor en la sede, don Feliciano de Figueroa, negó la licencia, pues «se mantubo en el dictamen que avía echo de que no saliese el santoral a luz, y, en vez de dar crédito a las razones de Casas, se afirmó más en el conzepto que havía formado de los hallazgos».

Frustrado Las Casas, escribió a su general que la única forma de solucionar el caso era someter los papeles al cardenal Bellarmino, una vez que habían desaparecido Arias Montano y don Juan Bautista Pérez y que él era el único instruido en el asunto. Se atendría al juicio del cardenal, y así «se sosegaría y aquietaría su conciencia y no bolvería a hablar palabra». Pero a esta maniobra se interpuso la actuación de don Pedro de Deza ${ }^{63}$, también cardenal en Roma, quien alertó a don Pedro Guerrero, tesorero del Sacromonte, destacado a la ciudad eterna para la defensa de los plúmbeos, quien a su vez envió sendos memoriales al asistente general y al general de la orden jesuítica y al propio Bellarmino, cuyo efecto fue «la uniforme deliberazión de mandarle a Casas que callase».

Los autores reproducen a la letra el dirigido al asistente general, padre Bartolomé Pérez. El tesorero desautoriza la opinión de Las Casas basándose en cinco razones: a) que la Compañía de Jesús en Granada en pleno es del parecer del arzobispo, tanto más tras el milagro de curación del padre Melchor de San Juan; b) que a partir de las versiones de tres libros, los priores, rectores, predicadores de las órdenes dominica, jesuítica, franciscana, agustina y demás radicadas en Granada «unánimes, aprobaron por doctrina sana y buena la contenida en aquellas versiones, y lo firmaron de sus nombres como consta de estos testimonios»; asimismo, el arzobispo de Zamora, don Hernando de Figueroa y Francisco Aguilar Terrones, antiguo contradictor, quien, viendo las invenciones con sus ojos, concluyó diciendo: «vean

${ }^{63}$ Deza es un personaje clave en la historia del Reino de Granada en la grave coyuntura de la guerra de los moriscos, pues formó parte de los «halcones», al dictado del cardenal Espinosa, presidente del Consejo de Castilla, desde la presidencia de la Real Chancillería de Granada y por poco tiempo la Capitanía General... Luego, fue elevado a la púrpura cardenalicia, en 1578, y residió en Roma, ostentando título y dignidad de Protector de España, hasta su muerte en 1600, a los ochenta años de edad. Conociendo su biografia anterior nada debe extrañar su decantación por el bando laminario. Vid. mi Granada morisca, la convivencia negada, 160-161 y 325 ss. 
todos los santos huesos, zenizas, olor y lugar con otras muchas circunstancias y captivarán el entendimiento»; c) que «el padre Ygnacio ni es tan letrado ni de tanta calidad que no se aia de tocar en esto viniendo en rompimiento»; d) que tras las denuncias de Las Casas a la Inquisición, se le envió a su convento desautorizado y al punto se escribió al arzobispo para que pasase a la calificación de las reliquias; e) que el rey estaba decantado por las reliquias, según la veneración que mostró al hueso de San Esteban, tal como el embajador duque de Sesa había comunicado a su santidad, a quien mostró el deseo regio de que se tratase la calificación según el Concilio de Trento, «como cosa de Yglesia de su patronazgo».

Fracasado su intento, Las Casas buscó el medio de influir en el dominico fray Jaime Bleda, «religioso de zelo y erudición», que por entonces escribía su Corónica de los moros de España, a quien mediante el halago convenció de la verdad de su posición:

Dióle sencillamente oydo aquel grabe religioso y, seducido de él, le aiudó no poco hasta la calificación a ponerle repetidos óbices, y, aun después, a desacreditar, aunque con timidez y paliadamente, tan grandioso echo.

En el capítulo 35, del libro 7, dedicado a martirios de España, Bleda refleja la opinión de su inductor, «las siniestras noticias que bebió de él, e, incauto, bertió después de su muerte por la pluma». Los relatores las recogen con algún detalle, que cabe ver en ese libro y lugar; ni siquiera resumirlas aquí, pues son largas. El apartado Bleda concluye - por el momento - con el lamento por el daño causado por el dominico y con la promesa de volver sobre él más adelante - como efectivamente sucede-, y, sobre todo, con una nueva condena de Las Casas por haber proporcionado información y papeles a terceros contra el juramento que en su momento hiciera al arzobispo, tanto más cuanto que no fue el único caso, como demuestra el del maestro agustino Juan González de Critana, etcétera.

Contrastan los autores «el tropel numeroso de las desacordadas cabilaciones de Casas» con «la roca firme del pecho del prelado en su constante fe y seguridad de lo averiguado en el proceso», quien antes que dejarse influir, se empeñó en cumplir la orden del papa reuniendo el Concilio Provincial que calificara las reliquias. Tras la consulta de los más doctos en la materia, puso en marcha los trámites, como fue recordar al nuevo rey, Felipe III, las consultas que ha- 
bía hecho con su padre, publicar la convocatoria «convidando a todos los prelados e yglesias del reino que quisieren authorizar el Concilio Provincial con su asistencia», y, en fin, encargando a todos los clérigos de su diócesis oraciones, ayunos y penitencias por la causa.

En el capítulo XXXV vuelven los relatores a ocuparse de la controversia; lo titulan de forma elocuente: «Origen de la complicación de ambos artículos y opuestos medyos y fines con que comenzaron a desacreditarse». Se redobla la diatriba contra Las Casas, y se retoma al padre Jaime Bleda, el otro de los hombres «de espíritu encontrado» de que se valió el «Abismo», ardiendo en cólera, para desacreditar los hallazgos: «Y lo consiguió con efecto entre los no instruidos en su malignidad». Por ello, los relatores se afanan en debelar «el modo astuto y raro arte» de sus acciones. Para una mejor argumentación adoptan la división de la materia en tres «artículos», según había distinguido la Santa Sede:

Uno, de la declaración de la santidad de las reliquias, que cometió a ultimar al prelado y lo ultimó en el concilio que queda referido [la calificación de 1600], y otro, de los escritos en árabe del pergamino y libros de plomo, de cuio contenido, en razón de doctrina, reserbó el juicio precisamente a su oráculo; mas, reflexando mejor la mente de los tres breves pontificios, se ve claro que dibidió la causa en otro artículo más que es el de hazer una versión puntual y fiel de los originales árabes.

Luego, orientan sus iras una vez más contra Las Casas, el primero de esos opositores, quien centró su «obstinada tenacidad» en el tercero de los artículos. Contra éste dirigió «todos los tiros en sus declaraciones y rapsodias, que continuó hasta su último vale, apuntando en ellas indirectamente al de la calificación de las reliquias». Para ello, acudió con sus delaciones al cardenal Bellarmino y al nuncio Domenico Gimnasio.

Fue avisado el arzobispo Castro de ello por algún «grave jesuita», $\mathrm{y}$, considerando que abusaba de su «caritativa tolerancia y natural modestia», escribió al nuncio una carta (en Granada, a 8 de octubre de 1600 ), en que denunciaba los libelos esparcidos por «este arábigo». Es procedente la reproducción literal, aunque sea en forma selectiva, pues da una idea del apasionamiento del arzobispo, que ni siquiera se recata de hacer reproches al nuncio por atender al intérprete sin haberlo consultado a él, a la vez que vierte descalificaciones contra el intér- 
prete opositor de inusitada dureza, entre la que no es la menor su condición de morisco. El escrito es sencillamente antológico:

Ese padre es persona sospechosa en esta materia, y por muchas razones no debe creerse en nada. Es morisco, hijo de gente vaja, y tiene un hermano renegado en Berbería; quizá le haze mal estómago ver que estos libros son contra toda la secta de Mahoma. No es theólogo, ni ha estudiado ni sabe la lengua árabe en que están estos libros; y afirmo que no sabe declinar un nombre. Tentó hazer aquí alguna tradución todo disparates, y él lo dexó como hombre que no lo entendía, y a la compañía le pesó mucho quando vio que yo le daba entrada sobre estas cosas y me lo contradixo. Tuvo ese padre en gran estimación este negocio y escrivió a su probincia muchas grandezas de él, y a mí en la carta que tengo aquí firmada de su nombre. Después tubo no sé qué pesadumbre en mi casa, con criados de ella, con que se hizo fiero enemigo. No sé si le movió esto a querer vengarse en este negocio. Movió su orden contra mí, atrebióse contra los breves de su santidad, haviéndoselos notificado, que pienso está escomulgado.

Recuerda luego las acciones de Las Casas ante la Inquisición y el rechazo por el tribunal; se ofrece a colaborar con el nuncio y la Santa Sede para que todo se aclare y, en fin, ruega al nuncio que medie ante el papa para que sosiegue el negocio.

El resultado inmediato fue que el nuncio remitió al prelado el memorial del «delator», que era el mismo que en su momento enviara a la Suprema y al inquisidor general don Pedro Portocarrero,

por cuio medio se hallan estos instrumentos en este archivo con otros que irán refiriendo en su oportunidad de libelos y cartas llenas de zizaña que sembró dentro y fuera del reino contra el tercer artículo, para que no se dude ni de su frenesí ni de su torcida intención.

Viendo Las Casas que sus intentos no surtieron los efectos deseados con el cardenal Bellarmino y los dos nuncios (sucesivamente Camilo Caetano y Gimnasio), "se enfureció su saña», e hizo otros seis sucesivamente ante: el inquisidor general, don Juan de Zúñiga, en 1602; su sucesor, don Juan Bautista Acevedo, en 1603; el rey, en 1604; el nuevo nuncio, don Juan García Milino, en 1605; su sucesor, don Decio Carrafa, en 1607, y, este mismo año, el papa Paulo V.

En todos los escritos late el mismo propósito, que, según las palabras de los relatores, se resume en

ponderar los graves inconbenientes que se seguirían en la Yglesia y en la Corona de España si no se cohibiese y corrigiese el culto declarado de las reliquias, por 
ser tan fuerte y estrecho el vínculo de éstas con el de los libros plúmbeos árabes, que no era posible persuadirse a que las reliquias eran de los primitibos mártires, discípulos de Santiago el Zabedeo, y que no fuesen authores de los libros los dos que referían las láminas.

Luego, individúan algunas de las razones técnicas que expuso Las Casas en sus libelos. Reproduzco esas razones literalmente, pero no las refutaciones que hacen los relatores, pues en todos los casos se limitan a poner énfasis en el hecho de que el intérprete primero alabara los escritos y luego los denigrara, aun habiendo sido aceptados como válidos por otros intérpretes de España y Roma; nunca entran en el fondo de las cuestiones. A Clemente VIII escribió Las Casas:

Quiero cerrar todo lo dicho del pergamino y caxa con una verdad llana y sin doblez: tuve yo en mi poder más de dos meses el pergamino original y hize toda la diligencia que pude (que fue mucha y mui grande) por interpretar lo arábigo; y, aunque la narración arábiga pareze fácil, tiene graves dificultades y términos, que unos yntérpretes dizen de una manera y otros de otra. Lo que careze de duda es que lo arábigo, escrito en escaques o casillas con tinta colorada y negra, está de tal suerte ilegible, que sin escrúpulo ninguno se puede jurar que ninguno de los yntérpretes acertó a copiar esto de verba verbus.

\section{A Paulo V escribió:}

Al principio, la grandeza de la cosa, la correspondencia del pergamino con las láminas, la forma de los libros, la gravedad del estilo del libro Fundamentum Eclesiae y su doctrina, el olor de los huesos y las zenizas, con los milagros que me referían aver acontecido, me inclinaron y persuadieron a creer que eran cosas de Dios y singulares merzedes y fabores echos a mi patria y grandísimos echos a mí en querer la Divina Magestad servirse de mí en tal y tan grave cosa. Pasando a interpretar otros, tropezaba mi entendimiento si serían cosas de Dios o engaños del demonio y sus ministros; y no hallaba camino en mi discurso para encadenar y trabajar lo que allí se decía con la verdad, gravedad y grandeza de las historias pasadas; y, aunque consideraba, que decía un libro, que era él todo alegorías y metáphoras y que la cortedad de mi entendimiento causaba el no parezerme bien y temer do no devía, y, aunque se me ofrecía también que ai en las sagradas letras muchas cosas mui dificultosas de acomodar al entendimiento no ilustrado con el don de la fe, no me sosegaba ni quadraba nada, pareciéndome mui diferente lo uno de lo otro... Y asentóseme en mi corazón con veras ser todas aquellas cosas trazas del enemigo de la Yglesia e invenciones de hereges, que con ficciones pretenden disminuir la gloria de Jesuxripto, Nuestro Señor, y de la Sacratísima Reina de los Ángeles, su madre, y alborotar su Yglesia.

No acaban de entender los relatores cómo «se complicó este travieso yntérprete», y en vez de construir un discurso «para encadenar y 
trabar lo que en ellos se decía con la verdad, gravedad y grandeza de las historias pasadas», acabó denigrando lo que había alabado con tanta convicción poco antes, de acuerdo con la opinión de los de su orden... Recuerdan que había escrito, en 1607, al papa Paulo V, aludiendo al libro Fundamentum Ecclesiae:

En sólo cinco ojas comprehende casi todos los artículos de la fe, con alto y grave estilo y lenguage, y me persuadí al principio que era el símbolo o concilio que hicieron los apóstoles viviendo Santiago antes de dibidirse a la predicación, y no estoi de contrario parezer.

Y cosa semejante en memoriales a los nuncios Caetano y Gimnasio:

Si no tuviera las dificultades que diré, juzgara que [es] el símbolo o concilio que hicieron los apóstoles después de la venida del Espíritu Santo, y no estoi de contrario parezer de que lo sea, aunque puede ser que hereges aian añadido algo para sus intentos, como suelen, y ojalá que fuera este libro sólo el descubierto, que por ventura de la Yglesia y el pontífice le admitieran por tal, y sólo él bastaba para authorizar y engrandezer a mi patria.

Estas observaciones sirven a los relatores para acusar a Las Casas de falta de teología, siguiendo al nuncio Gimnasio, quien lo había señalado en su momento:

Porque ¿cómo podía serlo [teólogo] quien confesaba estar en la persuasión de que era aquel libro el Símbolo Apostólico? No reparaba en el tropiezo del argumento que salía manifiestamente contra la providencia de Dios, de que huviese recatado a su Yglesia el fundamento de la fe y manifestádole con tanta liberalidad a los hereges, ni advertido la desigualdad increíble de que no se hubiese conservado entre los cathólicos (supuesta la constancia de la fe, que no ha faltado ni faltará en la Santísima Yglesia), y que, haviéndose desparecido a ésta desde el principio, huviese parado este instrumento en la diversidad de hereges que se fueron lebantando por siglos contra la religión y durado entre ellos, pasando de unos a otros, mudando de dueños y poseedores al paso de los hereges, hasta que últimamente hubiese caído en los orientales cismáticos que le trageron a sepultar en el Monte Santo de Granada, como vino a concluir este libelador al fin de su rapsodia...

La argumentación es prolija. La descalificación mantiene su contundencia habitual; «ligereza propria de un delirante», «su torcida intención o la ninguna theología», etcétera. Y reiteran la ignorancia, que resumen en unas palabras escritas por el intérprete morisco: «si 
no tuviera las dificultades que dixe». En definitiva, lo acusan de que «hizo concepto de que quanto él dificultaba tenía resabio de pernicioso, y sólo lo que sabía era seguro y verdadero». Se enredan luego en debatir una cuestión teológica concreta, «la procesión del Hijo por el Espíritu Santo» y otras cuestiones del Concepcionismo, que superan la intención de este artículo. Y afean con los peores dicterios el hecho de que se atreva a contradecir la doctrina de las reliquias cuando expresa la reserva de hablar de memoria, con dudas teológicas y servido de cortos fundamentos en la materia, por más que hubiera dejado escrito que aunque «los otros yntérpretes que ha habido saben más de la lengua arábiga que yo, no saben letras sagradas». Concluyen, no sin cierto ingenio:

Y si afectó noticias de letras sagradas, ¿por qué olbidó la máxima de los santos padres de que, hallando dificultad en alguna dicción de los antiguos, la atribuían a su ignorancia, sin atreberse a poner nota en lo que dexaron los primeros maestros firmado de sus nombres? Y lo que es más, ¿por qué se olbidó de la humana y menos humilde sabiduría del philósopho Sócrates, que, dándole a interpretar un obscuro libro de Heráclito, haviendo entendido unas sentencias mui buenas y no penetrado otras, preguntado qué le parecía, dixo: «Si lo que entiendo es tan bueno, creo lo será también lo que perzibo?»

Reafirman los autores su discurso en el hecho de que el asistente de su orden, Cristóbal de los Cobos (en carta datada en Valladolid, a 3 de marzo de 1606) le llame la atención por elevar quejas al nuncio por minucias, o el padre provincial (en carta datada en Córdoba, a 4 de abril de 1607), le recrimine no atenerse a la que parece la postura de la orden ante las reliquias -más fideísta y de empatía con la obra y persona del arzobispo Castro que de seria fundamentación teológica o histórica-, a la vez que «gradúa el achaque de incorregible o caprichudo» - adjetivación de los relatores-, con estas palabras:

Lo que vuestra reverencia me dize de los libros de Granada me causa novedad y admiración, porque yo asistí a la tradución de muchos de ellos, y, aunque no sé la lengua arábiga, no pudiera dexar de entender algo una vez $u$ otra, aunque los yntérpretes más lo quisieran disimular; y más, no saviendo ellos letra de theología. Fuera de esto, los milagros son tantos y las averiguaciones tan fuertes, que no sé yo que haia en España cosa más cierta que aquellas reliquias y, por consiguiente, los libros; que todo está tan trabado como vuestra reverencia save mejor; y diera mucho por averme hallado en Granada quando vuestra reverencia dudó de esta verdad que otras vezes me havía certificado tanto. 


\section{e) Complicaciones en el «orbe literario»}

Luego, se empeñan los relatores en dejar constancia de cómo Las Casas «lo complicó y malquistó en el orbe literario con la feroz zizaña de las siniestras noticias que coacervó en su idea y sembró con sus cartas en el candor de los más zélebres escriptores de aquella edad». En efecto, explayan con algún detalle la influencia en el dominico Jaime Bleda, ya aludido - le dedicaban el amplio espacio de 11 parágrafos, los 591 a 601 ; y vuelven a él- sobre el padre jesuita Francisco Suárez, el «doctor eximio», que lo tuvo en gran estima, sobre el cardenal Baronio y sus Annales, sobre fray Antonio Posevino, sobre Spondano, sobre el cardenal Bollando... ${ }^{64}$.

Cabe acabar esta ya demasiado larga exposición con el mentado Bleda. Los relatores extraen intencionadamente una cita de su Corónica, que nos parece muy expresiva, no sólo de la influencia que en efecto ejerció Las Casas sobre «su amigo», sino sobre la propuesta evangelizadora de los moriscos, amén de la sugerencia de acercamiento más racional a los hallazgos. Escribe Bleda, y los relatores transcriben a su modo ${ }^{65}$ :

Propuso esta causa el padre Ygnacio al sumo pontífice Clemente VIII y después a nuestro señor Paulo $\mathrm{V}$ valiéndose del fabor de los ylustrísimos señores cardenales Bellarmino y Baronio, representando a su santidad un arbitrio a su parezer forzoso para remedio de esto que diversas vezes avía dado al rei nuestro señor, en particular el año de 1604, aquí en Valencia, quando se celebró Cortes, y finalmente al sumo pontífice Paulo V el año de 1607. Y era que theólogos mozos, así de varias religiones, como de otros, deprendiesen en quatro o cinco años la lengua arábiga y con esto se entendería ésta su verdad a cerca de las dichas láminas y sirvieran a la Yglesia y a estos reinos no sólo en esto, sino en todo lo que el dicho padre Ygnacio tenía apuntado en un tratado particular, en que daba por fácil la conversión de los moriscos de España si se les predicaba en su lengua; la qual este padre se ofrecía a enseñar, y avía buen aparejo para ello y para sustentar a los theólogos que la aprendiesen en un seminario de los obispos ${ }^{66}$ de Valencia, donde sin provecho ninguno se han gastado tantas rentas en sustentar hijos de

\footnotetext{
${ }^{64}$ Ésta es materia para otra ocasión, para otro trabajo complementario de éste, pues los implicados son personalidades de mucha entidad y sus obras tuvieron trascendencia en diversos campos eclesiales. En la Historia authéntica ocupan los parágrafos 699-709; y hubiera seguido el relato en el padre jesuita Jerónimo Román de la Higuera en el punto en que se corta la obra (prf. 710).

65 Reproducen el texto de Bleda con bastante exactitud, aunque con licencias en la ortografia. Véase su Corónica, 841-842.

${ }^{66}$ En la Corónica se lee «moriscos» en vez de «obispos».
} 
moriscos, aun después de su general expulsión, sin que advierta este daño a quien lo pueda remediar.

Es del mayor interés la apostilla de los relatores a esta larga cita, pues reconocen algo que el hombre de hoy valora como un gran progreso y que sería imputable en mayor medida al continuo bregar de Las Casas, la incorporación del árabe en los estudios universitarios. Dicen:

Bien pudiera este escritor aver añadido a esta relación el fruto que hizo en la santidad de Paulo V el insinuado arbitrio, espidiendo la bula que se lee entre sus constituciones ordenando que en todos los estudios de qualquier orden e instituto de regulares se enseñasen las lenguas hebrea, griega y latina, y, en las maiores y más zélebres universidades, también la lengua árabe.

Se lamentan de que «calló este fruto, aunque le constó». Presentan en fin a Bleda como ejemplo acabado de la mala influencia de los libelos de Las Casas, «pues es cierto se contiene en ellos el arbitrio que machinó para hazer en el orbe literario el papel que no avía podido hazer en los inventos». En las palabras que siguen del papelista dominico creen ver «hasta dónde echó el resto la sugestión del arbitrista»:

Prevaleció la pía opinión a cerca de las dichas reliquias por aver parecido al arzobispo ordinario después de muchas juntas y parezeres que era servicio de Dios, Nuestro Señor, declarar que las dichas reliquias eran indubitadamente de los santos que en las minas se nombran. Y yo así lo creo mientras el vicario de Xripto no determina otra cosa en contrario.

\section{Recapitulando}

En la obligada recapitulación final conviene hacer una primera observación: el que aquí concluye es un trabajo más de los muchos que reclama el Sacromonte de Granada y su entorno espacial (capital y reino); ni mucho menos, el final y acabado de una labor investigadora (aunque responda a una sostenida dedicación). Con el tiempo será componente de un libro que preparo sobre la historia de esa institución. Como en toda ella, se refleja la triple característica que la informa, fraude, mito, legado, que le confiere una gran complejidad. Basta echar una ojeada a la nota biblio-historiográfica del comienzo para hacerse una idea. La tarea de una «obra definitiva» se antoja imposi- 
ble hoy mismo, pero se hace necesario seguir aportando trabajos sustanciales, con nuevos planteamientos y ambiciones, con gran voluntad crítica, que arrebate la iniciativa de la investigación de manos de historiadores interesados en mantener y legitimar el mito contra toda evidencia, lacra que se percibe demasiado claramente, cuatro siglos después, desde el solar mismo donde se produjeron los hallazgos. Acaso esta preocupación presentista ${ }^{67}$ descubra en algún momento ciertas aristas críticas demasiado ostensibles que en el futuro habrá que ir afinando con más matizados argumentos y con la perspectiva y ayuda de otros estudios paralelos. En cualquier caso, la aportación procura no traicionar el propósito de nuestras advertencias preliminares.

En otro plano, la extensión de la exposición, la cantidad y diversidad de episodios y de elementos implicados y, sobre todo, el recurso deliberado a la textualidad en su parte nodal obligan a una recapitulación donde se condensen las líneas maestras de la aportación. Eso se pretende en las palabras que siguen.

Arriba (en el apartado II) ha quedado expresada la triple actividad de Ignacio de las Casas, constante y esforzada: en el apostolado social, en el misional con los de su nación y en el estudio y refutación de los libros plúmbeos. En el campo social, como activo trabajador que fundó congregaciones para artesanos y oficiales en España e Italia, en los lugares donde residió. En el campo misional, como evangelizador de sus hermanos moriscos, de forma consecuente con la formación y fe cristiana integral, sincera y militante, sin mostrar en ningún momento la más mínima complacencia con los islamizantes, propugnando y aplicando los métodos de evangelización pacífica o suave, no compulsiva en definitiva, que había aprendido en su etapa de formación y que eran los propios de la compañía, en lo que el empleo del árabe era instrumento inexcusable; además de luchar incansablemente por evitar que los moriscos fueran expulsados de tierras hispanas. Virtudes y acción que le hacen un merecido hueco en la historia de los de su orden ${ }^{68}$ y en el aspecto concreto de la evangelización y apostolado con los moriscos y los desheredados.

\footnotetext{
67 A la que no ha sido, por cierto, ajena Mercedes García-Arenal cuando preparaba la sección monográfica sobre los libros plúmbeos de esta revista (XXIII-2, 343)

${ }^{68}$ Lo cual no ha impedido que la compañía haya impuesto la «ley del silencio» sobre Las Casas, dado «el elevado número de jesuitas laminarios» (G. Morocho, op. cit., 274).
} 
Ignacio de las Casas, sin embargo, ha llamado mayormente la atención del historiador, entrando en el áspero reino de la controversia, por su tercer ámbito de actividad, por ser el más pugnaz y constante opositor al fraude de los libros plúmbeos. Es título que no le han regateado la legión de detractores de la memoria, es decir, todos los laminarios que en el mundo han sido desde su perseguidor en vida, Pedro de Castro, hasta los de nuestros días. Esta faceta es la que hemos traído en esta ocasión, pero no conviene olvidar que todas, aquéllas y ésta juntamente, redondean la personalidad y explican la coherencia de la actuación, a la vez que disipan cualquier duda sobre la entrega a la causa cristiana y la recta conciencia, en definitiva, la superioridad moral del personaje. No en vano ha sido calificado, por quien más críticamente se ha acercado a la cuestión de los plúmbeos y con mayores y mejores argumentos documentales, de «eminente y venerable jesuita» y puesto su nombre junto a los más ilustres antilaminarios: Benito Arias Montano, Juan Bautista Pérez y Pedro de Valencia ${ }^{69}$.

Hemos seguido la historia del intérprete morisco en su tormentosa relación con las invenciones sacromontanas, aun la menuda, llena de sucesos incontables, en el relato de la Historia authéntica, de Viana y Laboraría. No es difícil su resumen en los rasgos más sobresalientes merced a la linealidad cronológica adoptada en la exposición y aun su objetivación por encima de la redundancia de las descalificaciones ${ }^{70}$. Empezó alabando los libros plúmbeos, en sus primeros descubrimientos, mas, cuando el trabajo lo fue introduciendo en el verdadero conocimiento de la materia, la certeza se fue tornando en duda, para acabar en oposición frontal: ese paso de $\mathrm{Pa}-$ blo a Saulo... ${ }^{71}$. El arzobispo intentó silenciarlo a través de sus superiores de orden, de la Inquisición y de las jerarquías romanas. No lo consiguió. Las Casas no obedeció, y denunció el fraude en cuantas partes alcanzaba. Sin embargo, no pudo impedir que el papa Clemente VIII decretara la separación de reliquias y láminas plúmbeas,

69 Ibidem, 274. Lo que no descarta que en la controversia laminaria se viera movido en alguna medida por el «amor propio», pero en modo alguno en la forma en que insisten sus detractores (vid. Benítez, R., «De Paulo a Saulo», 404).

${ }^{70}$ Que no damos por buena en sus detalles. Vid. la historia como la cuenta el padre Carlos Alonso, O. S. A., Los apócrifos, passim, y especialmente el capítulo X, 160-178.

${ }^{71}$ Que tan gráficamente ha captado R. Benítez, «De Pablo a Saulo». 
ni que un concilio reunido en Granada por Pedro de Castro, en 1600, calificara de auténticas las reliquias.

Las Casas no se doblegó; siguió manteniendo el argumento de que no podía separarse el «artículo» de la calificación de las reliquias del de los libros, pues la estrecha imbricación saltaba a la vista: tan falsas eran unas como las otras. La desatención a estas propuestas, siendo el fraude tan evidente, radicalizó su oposición. Los escritos de denuncia se redoblaron en el último tramo de vida a todas las instancias posibles (cortes de Madrid y Roma, Inquisición, superiores de su orden, otras jerarquías eclesiásticas españolas), procurando influir con sus opiniones en tratadista y teólogos muy sobresalientes (padre Suárez, Jaime Bleda, Baronio...). No logró todos los objetivos. Sin embargo, la reducción fue imposible. Es más, la oposición fue tan notoria, que los activos agentes sacromontanos ni siquiera pudieron falsificar una retractación en los papeles, tal como hicieron con Pedro de Valencia, el arzobispo de Montelíbano (Juan el Hesronita), Mendiola, Gurmendi, Juan Bautista Pérez, Mármol Carvajal, Terrones..., antilaminarios convencidos ${ }^{72}$.

La impotencia llevó al arzobispo a verter las peores descalificaciones de la persona del oponente. A los argumentos y escrúpulos de Las Casas, nunca respondió con razones que fueran al fondo de la cuestión, reduciendo sus diatribas al terreno meramente personal, un ataque ad hominem inmisericorde, de difícil parangón. Castro lo descalificó con los peores dicterios: ser morisco, de gente baja, no soportar que los libros plúmbeos iban contra la secta de Mahoma..., de ser ignorante en lenguas orientales y en teología... y, de forma reiterada, de que su cambio respecto de los hallazgos se debió a rencores personales con él y con los de su casa, únicos que, en su extravío fanático, podían explicar el paso radical de la loa a la denuncia y a la extrema pugnacidad de su postura.

Conviene subrayar que las acusaciones y descalificaciones de Castro, incapacitado para ver más allá de su propia obsesión, fueron la base de la condenación de la memoria, la estigmatización del jesuita morisco, que articularon los laminarios posteriores, albaceas ideológicos del mentor carismático, el fundador, a quien emulaban en fanatismo. Sobre esa base, acrecida por la frustración de la condena de

72 Vid. Morocho, G., op. cit., 332-334. 
1682, los incondicionales, y Viana y Laboraría como sujetos sacromontanos consecuentes lo eran en grado superlativo, le inventaron la biografía falsa que se ha explayado por extenso como eje de la exposición: alimentaron la imagen de un niño perverso, sujeto caprichoso luego, medrador enfermizo, fugado de forma vergonzante de la capital tan pronto como se descubrió la artimaña para acaparar las láminas, con acusaciones de ser causa de todos los males que aquejaban a los hallazgos, de sembrar la cizaña dentro y fuera del reino, faltando al juramento de mantener el secreto de los contenidos y de envenenar con falsedades a otros tratadistas, etcétera; todo ello trufado de la peor adjetivación posible.

Los laminarios que siguieron a Castro sabían que la pervivencia de su obra, basada en una superchería demasiado burda, se afianzaba tanto en la alabanza del fundador y de sus fundaciones como en la condenación de los detractores de las invenciones, sin reparar en los medios. Los del siglo XVIII, fueron los que forjaron el «espíritu sacromontano» que concreta esas intenciones para la posteridad; quien mejor entendió el mensaje del fundador fue Luis Francisco de Viana - el papel de Laboraría se nos antoja secundario-; la Historia authéntica lo demuestra. Sería un ejercicio morboso repetir aquí la enormidad de las descalificaciones que se vierten a lo largo de los capítulos que se ocupan de Las Casas. Empero, el relato presta un gran servicio al estudioso, pues, aun admitiendo el descarado sesgo de las interpretaciones, la búsqueda de la verosimilitud, de la plausibilidad, cierto que contando con la complicidad del destinatario, les lleva a ofrecer abundante documentación del Archivo Secreto del Sacromonte no siempre accesible. Los mismos documentos que esgrimen para la condenación de la memoria - aun admitiendo que hacen la selección que va su propósito - pueden ser leídos en sentido muy contrario a sus fines. La abundante letra del relato, detallado y mostrativo, es, para el investigador avisado, un buen elemento de comparación y cotejo con otros muchos papeles que se guardan en archivos nacionales y extranjeros, incluidos los de Roma y los de la propia Abadía del Sacromonte ${ }^{73}$.

\footnotetext{
73 De ahí que a mayor abundamiento presente la transcripción de los textos en la sección de documentos de la revista Chronica Nova, 29.
} 


\title{
RESUMEN
}

Sobre los pasajes concretos de la Historia authéntica, de Luis Francisco de Viana y Bustos y Joseph Juan de Laboraría, canónigos del Sacromonte de Granada, se evoca la condenación de la memoria que esta institución hace para la historia, del padre Ignacio de las Casas. Éste, jesuita granadino, morisco de nación, misionero con sus hermanos y trabajador social por donde pasó, campos en los que ganó merecido prestigio, se significó como acérrimo refutador de las invenciones de la Torre Turpiana y Valparaíso de fines del siglo XVI. El arzobispo Pedro de Castro lo persiguió en vida y, luego, decidió para los siglos posteriores la estigmatización de su memoria, que implicaba el falseamiento y envilecimiento de su biografia. La Historia authéntica, defensorio escrito en 1756, es la mejor expresión del fanático cumplimiento de ese mandato del fundador carismático, siglo y medio después de los hallazgos.

\begin{abstract}
Using specific pasages from the Historia authéntica by Luis Francisco de Viana y Bustos and Joseph Juan de Laboraría, canons of the Sacromonte of Granada, the article evokes the condemnation carried out by this institution of the historical memory of father Ignacio de las Casas. This later was a Jesuit from Granada, Morisco by birth, and a missionary and social worker of considerable prestige who had distinguished himself as a staunch refuter of the Torre Turpiana and Valparaíso inventions of the late $16^{\text {th }}$ century. De las Casas was persecuted during his own lifetime by the charismatic archbishop Pedro de Castro, founder of the Sacromonte Abbey and later responsible for the stigmatisation for future centuries of de las Casas' memory throught the falsification and debasement of his biography. The Historia authéntica, a "defensorio" (written in 1756) provides the best example of the fanatical fulfilment of the founder's instructions, 150 years after the controversial findings.
\end{abstract}

